\title{
Diet and Economic Modelling to Improve the Quality and Affordability of the Australian Diet for Low and Medium Socioeconomic Households
}

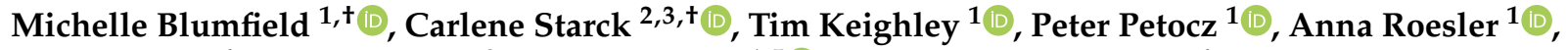 \\ Kylie Abbott ${ }^{4}$, Tim Cassettari ${ }^{2}$, Skye Marshall 1,5 (D) and Flavia Fayet-Moore ${ }^{4, *}$ \\ 1 Department of Science, Nutrition Research Australia, Sydney, NSW 2000, Australia; \\ michelle@nraus.com (M.B.); tim.keighley@gmail.com (T.K.); Peter.petocz@mq.edu.au (P.P.); \\ anna.roesler@flinders.edu.au (A.R.); skye@nraus.com (S.M.) \\ 2 Department of Translational Science, Nutrition Research Australia, Sydney, NSW 2000, Australia; \\ carlene@nraus.com (C.S.); tim@nraus.com (T.C.) \\ 3 Riddet Institute, Massey University, Palmerston North 4474, New Zealand \\ 4 Nutrition Research Australia, Sydney, NSW 2000, Australia; kylie@nraus.com \\ 5 Bond University Nutrition and Dietetics Research Group, Faculty of Health Sciences and Medicine, \\ Bond University, Gold Coast, QLD 4226, Australia \\ * Correspondence: flavia@nraus.com; Tel.: +61-4-015-990-050 \\ + These authors contributed to this work equally.
}

Citation: Blumfield, M.; Starck, C.; Keighley, T.; Petocz, P.; Roesler, A.; Abbott, K.; Cassettari, T.; Marshall, S.; Fayet-Moore, F. Diet and Economic Modelling to Improve the Quality and Affordability of the Australian Diet for Low and Medium Socioeconomic Households. Int. J. Environ. Res. Public Health 2021, 18, 5771. https://doi.org/10.3390/ ijerph18115771

Academic Editors: Ce Shang, Nigar Nargis and Frank J. Chaloupka

Received: 6 April 2021

Accepted: 22 May 2021

Published: 27 May 2021

Publisher's Note: MDPI stays neutral with regard to jurisdictional claims in published maps and institutional affiliations.

Copyright: $\odot 2021$ by the authors. Licensee MDPI, Basel, Switzerland. This article is an open access article distributed under the terms and conditions of the Creative Commons Attribution (CC BY) license (https:// creativecommons.org/licenses/by/ $4.0 /)$.
Abstract: Food costs are a barrier to healthier diet selections, particularly for low socioeconomic households who regularly choose processed foods containing refined grains, added sugars, and added fats. In this study, the objectives were to: (i) identify the nutrient density-to-cost ratio of Australian foods; (ii) model the impact of substituting foods with lower nutrient density-to-cost ratio with those with the highest nutrient density-to-cost ratio for diet quality and affordability in low and medium socioeconomic households; and (iii) evaluate food processing levels. Foods were categorized, coded for processing level, analysed for nutrient density and cost, and ranked by nutrient density-to-cost ratio. The top quartile of nutrient dense, low-cost foods included 54\% unprocessed (vegetables and reduced fat dairy), 33\% ultra-processed (fortified wholegrain bread and breakfast cereals $<20 \mathrm{~g}$ sugars $/ 100 \mathrm{~g}$ ), and 13\% processed (fruit juice and canned legumes). Using substitution modelling, diet quality improved by $52 \%$ for adults and $71 \%$ for children across all households, while diet affordability improved by $25 \%$ and $27 \%$ for low and medium socioeconomic households, respectively. The results indicate that the quality and affordability of the Australian diet can be improved when nutritious, low-cost foods are selected. Processing levels in the healthier modelled diets suggest that some ultra-processed foods may provide a beneficial source of nutrition when consumed within national food group recommendations.

Keywords: diet; cost analysis; affordability; food security; diet quality; food-processing; socioeconomic

\section{Introduction}

The habitual diets of Australians are characterized by an inadequate intake of the recommended core food groups and overconsumption of discretionary foods (those not necessary to provide essential nutrients), leading to insufficient intakes of dietary fiber, vitamin A, vitamin D, folate, calcium, and iron, as well as excessive intakes of added sugars, saturated and trans fats, and sodium [1-3]. Processed and ultra-processed foods represent over $40 \%$ of foods consumed by Australians [4], and have been suggested to contribute to unhealthy dietary patterns and the subsequent increased risk of noncommunicable diseases (e.g., type 2 diabetes and cardiovascular disease) and mental illness [4-6]. Therefore, the diet quality of the Australian population remains a public health priority $[7,8]$. 
A key barrier to equal access of healthy diets is cost, which is particularly relevant in the 2020-2021 Australian recessionary environment [9]. The International Network for Food and Obesity/NCDs Research, Monitoring and Action Support (INFORMAS) protocol provides a framework for examining the price differential of healthy and unhealthy diets $[10,11]$. Dietary modelling using the INFORMAS protocol has shown that a healthy diet can cost less than the current Australian diet, across a range of household types and socioeconomic status (SES) positions [12]. However, the healthy diet is lower in energy, and dietary modelling in New Zealand suggests that when diets are matched for energy a healthy diet becomes more expensive $[13,14]$. Food prices vary across Australia, with rural and remote areas showing prices that are up to $40 \%$ higher than those in capital cities [7]. The contribution of the food environment to both diet quality and affordability reveals a need for greater understanding about the relationship between nutrition and food cost in Australia, particularly in vulnerable groups.

When food costs are greater than $25 \%$ of disposable income, a household is considered to be in 'food stress', and when greater than $30 \%$ of disposable income, a healthy diet becomes 'unaffordable' [9]. Lower and medium SES households in Australia spend a greater proportion of their income on food (15-27\% and $12-18 \%$, respectively) as compared with higher SES households (9-13\%) [15]. Lower and medium SES households are most affected by regional variations in food prices, inflation, and government policies [7]. Research from the USA [16] and New Zealand [17] have identified a selection of nutrient dense, low-cost foods, including milk, potatoes, breakfast cereals, and eggs [16,17]. However, it is unclear whether similar low-cost foods can be applied in Australia to create a healthier diet, and if these foods positively impact diet quality and affordability for Australian households.

Processed and ultra-processed foods that contain refined grains, added sugars, and added fats have been highlighted as some of the lowest-cost sources of dietary energy, and represent both core (contributing to nutrient requirements) and discretionary (negligible contribution to nutrient requirements) foods [18]. Although ultra-processed foods are linked with poor diet quality and negative health outcomes, a recent study of foods in the USA found that $17 \%$ and $33 \%$ of ultra-processed and processed foods, respectively, can be classified as nutrient dense [19], and some ultra-processed and processed foods have been classified as both low-cost and nutrient dense (e.g., fortified cereals, beans, milk, and yoghurt) $[20,21]$. The NOVA processing classification system is the most widely used method for categorizing foods according to their processing level (unprocessed or minimally processed, culinary processed, processed, and ultra-processed) [22]. Australian research has highlighted some disagreements between NOVA classifications and dietary guidelines [23], where some ultra-processed foods are core foods rather than discretionary. Therefore, processing level should be considered when investigating nutrient dense, lowcost foods and their impact on diet quality and affordability in Australia.

To understand this complex relationship between healthy food and affordability, this study aimed to: (i) identify the nutrient density-to-cost ratio of Australian foods, (ii) model the impact of substituting foods with lower nutrient density-to-cost ratio with those with the highest nutrient density-to-cost ratio on diet quality and affordability for low and medium socioeconomic households, and (iii) evaluate food processing level. It is hypothesized that substituting foods in the current diet with foods in the top quartile of nutrient dense, low-cost foods will improve the quality and affordability of modelled diets.

\section{Materials and Methods}

This study was informed by the INFORMAS protocol [11] and reported according to the Strengthening the Reporting of Observational Studies in Epidemiology (STROBE) checklist for cross-sectional studies [24], and Consolidated Health Economic Evaluation Reporting Standards (CHEERS) Statement [25]. 


\subsection{Nutrient and Food Price Databases}

\subsubsection{Australian Food and Nutrient Database}

The Australian Food and Nutrient (AUSNUT) 2011-2013 database was developed by Food Standards Australia and New Zealand (FSANZ) to enable food, dietary supplement, and nutrient intake estimates to be made from the 2011-2013 Australian Health Survey [26]. The AUSNUT database was selected for this study in preference to the current Australian Food Composition Database; therefore, the composition could link directly with dietary intake data, sourced from the Australian 2011-2012 National Nutrition and Physical Activity Survey (NNPAS) [3]. The AUSNUT database contains macro- and micronutrient composition data for 5740 Australian foods, and organizes foods according to a major (2-digit coded, 22 food groups), sub-major (3-digit coded, 132 food groups), and minor (5-digit coded, 515 food groups) food group, with individual foods given an 8-digit code. The 8-digit code forms the basis of a survey ID within the NNPAS [26]. In this study, sub-major (3-digit coded) food groups were aggregated into a reduced number of food categories; a method previously used in dietary modelling, to simplify and combine similar food groups [27]. Mixed dishes, takeaway foods, breads and rolls with flour not defined, organ meats and offal, tea and coffee, water, alcohol, supplements, infant formula, and baby foods were excluded in this study due to the following: being unfeasible to model as individual food categories (e.g., mixed dishes and takeaway foods); contributing negligible calories to the diet (e.g., tea and coffee, water, and supplements); contributing negligible nutrients to the diet (e.g., alcohol); or being consumed in low frequency (e.g., breads and rolls with flour not defined, organ meats and offal, infant formula, baby foods). A total of 57 food categories were analyzed (Table S1).

Within each food category, three representative foods were selected for being the lowest in cost and readily available in major Australian supermarkets, as informed by the INFORMAS protocol [11]. Nutrient data for each food category were based on the average nutrient composition of the three representative foods within each category, obtained from the AUSNUT survey ID (8-digit code). Minor (5-digit coded) food groups were used to classify food categories according to level of fortification (if fortified or not). NOVA processing levels were applied (unprocessed/minimally processed, culinary processed, processed, and ultra-processed).

\subsubsection{Food Price Database}

An Australian food price database was created according to the INFORMAS protocol [11] and published elsewhere [28]. Food price data were collected from two supermarkets (Coles and Woolworths) each located in a low (Merrylands and Auburn) and medium (Zetland and Burwood) metropolitan SES area within the state of New South Wales, Australia, from 7 December to 11 December 2020. Locations were selected based on the Australian Bureau of Statistics Index of Relative Socioeconomic Advantage and Disadvantage (IRSAD) [29]. The IRSAD summarizes information about the economic and social conditions of people and households within an area by postcode, taking into account both relative disadvantage and advantage [29]. The index ranks areas on a continuum (1 to 10) from most disadvantaged to most advantaged. IRSAD quintiles 1 and 3 were chosen to represent low and medium SES areas, respectively [29].

Price data were collected for each representative food according to the following criteria: (i) the lowest non-discounted price was chosen for the most commonly available product size; (ii) the product was widely available nationally; (iii) fresh produce of poor quality was omitted; and (iv) if a specified product was not available, a similar product or the closest alternative based on its nutrient composition was selected (e.g., a pear if apple unavailable). One sample was collected per representative food product per store, and the average food price per $100 \mathrm{kcal}$ was determined [16,30]. 


\subsubsection{Dietary Intake Database}

Dietary intake data were obtained from the NNPAS [3], in order to construct a current diet that accurately represented the Australian population from both low and medium socioeconomic areas. The NNPAS is a nationally representative survey that forms part of the 2011-2013 Australian Health Survey ( $n=9341$ adults and $n=2812$ children) [31]. The automated multiple-pass 24-hour dietary recall method was used to capture all foods and beverages consumed by respondents within the 24 hours prior to the interview day. For children aged 2-14-years, an adult was interviewed on the child's behalf. This study excluded repeated 24-hour recalls which were performed on a subsample of the participants. Further survey details including sampling methodology and response rates are available in the Australian Health Survey Users' Guide, 2011-2013 [32].

\subsection{Categorization of Food Categories by NOVA Processing Level and Discretionary Status}

Each food category was coded according to its level of processing using the NOVA classification system $[22,33,34]$ as follows: Group 1 , unprocessed or minimally processed foods (e.g., rice, pasta, traditional breads and other cereals, meat, fish, milk, eggs, fruit, roots and tubers, vegetables, nuts, and seeds); Group 2, processed culinary ingredients (e.g., sugar, plant oils, and butter); Group 3, processed foods (e.g., processed breads and cheese, canned foods, and salted and smoked meats); Group 4, ultra-processed foods (e.g., confectionary, savory snacks, fast food dishes, ready-to-eat breakfast cereals, mass-produced packaged breads, frozen and ready meals, and soft drinks). We followed a previously published methodology [4]. Two accredited practicing dietitians (APDs) independently applied the NOVA classification system to each food category. Where a food category contained more than one processing level, the processing level that occurred in the highest proportion of foods within that food category was selected (e.g., legumes and legume dishes were categorized as processed). Any differences in classifications were discussed in the first instance or resolved by a third APD.

Food categories were further coded as non-discretionary or discretionary, according to the Australian Bureau of Statistics discretionary food list [35]. If a food category contained both discretionary and non-discretionary foods, the status occurring in the highest proportion of foods within that food category was selected (e.g., ready-to-eat fortified breakfast cereals with greater than $20 \mathrm{~g}$ sugars $/ 100 \mathrm{~g}$ were categorized as discretionary, although some $(<50 \%)$ of the breakfast cereals within that category were not discretionary).

\subsection{Dietary Modelling Protocol}

The dietary modelling protocol is summarized in Table 1.

Table 1. Summary of the major steps involved in the protocol to model nutrient dense, low-cost diets.

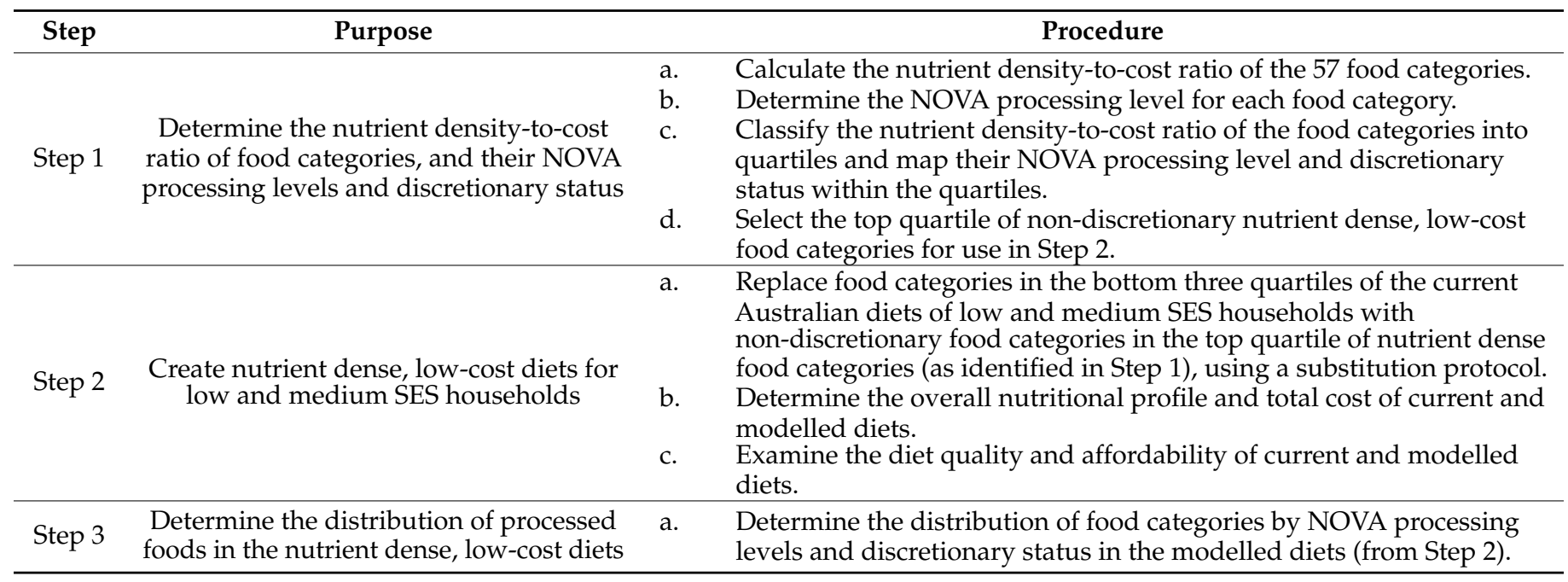




\subsubsection{Step 1: Nutrient Density-to-Cost Ratio of Food Categories and NOVA Processing Levels}

The Nutrient Rich Food Index (NRF9.3) per $100 \mathrm{kcal}$ was calculated for each food category [36]. The index assesses the proportion of nutrient requirements that are provided by a food, in relation to energy $[16,36]$. There are nine positively weighted nutrients (protein, dietary fiber, calcium, iron, potassium, magnesium, and vitamins A, C, and E), and three negatively weighted nutrients (saturated fat, added sugars, and sodium). Food categories with the highest NRF9.3 scores contain higher levels of the positively weighted nutrients and negligible levels of the negatively weighted nutrients. The NRF9.3 was adapted for the Australian Dietary Guidelines and Nutrient Reference Values (Supplementary Methods S1) and a constraint that the ratio could not fall below zero was applied. The nutrient density-to-cost ratio for each food category was calculated as the mean of the ratios for the representative foods chosen in each food category. Food categories in the highest quartile of nutrient density-to-cost ratio were considered to be 'nutrient dense and low-cost' foods.

\subsubsection{Step 2: Substitution Modelling to Create Low-Cost, Healthier Diets}

Current Australian diets for low and medium SES households were constructed using the food categories developed in Step 1. The reference household structure was comprized of four individuals: female, 7 years; male, 14 years; female, 45 year; and male 45 years, as informed by the INFORMAS protocol [11]. The reference household was used for both low and medium SES groups [29]. To maximize the sample size, reference ages were expanded to reflect the age groups in the Australian Nutrient Reference Values as follows: female, $4-8$ years; male, $9-13$ years; female, $31-50$ years; and male, $31-50$ years [37]. The demographics of the low and medium SES households modelled in the current study are outlined in Table 2. The most recent equivalized disposable income per week for both low and medium SES households was sourced from the 2017-2018 Australian Survey of Income and Housing [38], which used the Organization for Economic Co-operation and Development (OECD) equivalized disposable income. This is multiplied by an adjustment factor to equivalize to the INFORMAS reference household [11]. For a 4-person household, the OECD adjustment factor is 2 . Total household dietary intakes were calculated by summing the daily intakes of all household members and multiplying by 7 to provide dietary data over a week. The cost of each diet was expressed as a percentage of the disposable income for each household per week to reflect affordability.

All substituted healthier diets aimed to meet Australian food group recommendations, with no allowance for discretionary foods [39]. The Australian core food groups were labelled as fruit, vegetables, cereals and grains, dairy and alternatives (milk, yoghurt, cheese, and/or alternatives), meat and alternatives (lean meat, fish, poultry, eggs, tofu, nuts, and legumes), and other foods (margarines and edible oils). An algorithm was created to replace food categories in the current diet with food categories from the highest quartile of nutrient density to cost, as identified in Step 1 of the modelling protocol. Each substitution was made according to the 'like for like' principle, whereby each food category in the current diet was substituted for a healthier (more nutrient dense) version of that food, keeping as close to the original food as possible. For example, white bread was substituted with wholegrain bread or processed meat was substituted with lean fresh meat. Discretionary foods were replaced according to the same 'like for like' principle, with one discretionary serving equivalent to $150 \mathrm{kcal}$. The algorithm was checked for logical output using key foods. Full detail regarding the substitution rules is provided in Supplementary Methods S2 and Table S2. 
Table 2. Demographics of low and medium SES reference households.

\begin{tabular}{|c|c|c|c|}
\hline Indicators 1 & Low SES Household & Medium SES Household & $\begin{array}{l}\text { Low vs. Medium } \\
\text { SES Household } \\
(p \text {-Value })^{5}\end{array}$ \\
\hline & $\begin{array}{l}\text { 4-person reference } \\
\text { household in the lowest } \\
\text { quintile of SES position }\end{array}$ & $\begin{array}{l}\text { 4-person reference } \\
\text { household in the middle } \\
\text { quintile of SES position }\end{array}$ & \\
\hline \multicolumn{4}{|l|}{ Male (31-50 y) } \\
\hline$n$ & 281 & 324 & \\
\hline Age (years) & $40.1(5.8)$ & $40.8(5.9)$ & 0.142 \\
\hline $\mathrm{BMI}^{2}$ & & & 0.248 \\
\hline Underweight, $n(\%)$ & $2(0.8 \%)$ & $2(0.7 \%)$ & \\
\hline Normal, $n(\%)$ & $78(32.0 . \%)$ & $72(25.2 \%)$ & \\
\hline Overweight, $n(\%)$ & $99(40.6 \%)$ & $139(48.6 \%)$ & \\
\hline Obese, $n(\%)$ & $65(26.6 \%)$ & $73(25.5 \%)$ & \\
\hline \multicolumn{4}{|l|}{ Female (31-50 y) } \\
\hline$n$ & 301 & 408 & \\
\hline Age (years) & $40.2(5.6)$ & $40.1(5.6)$ & 0.814 \\
\hline $\mathrm{BMI}^{2}$ & & & 0.009 \\
\hline Underweight, $n(\%)$ & $5(2.0 \%)$ & $1(0.3 \%)$ & \\
\hline Normal, $n(\%)$ & $89(35.2 \%)$ & $143(42.6 \%)$ & \\
\hline Overweight, $n(\%)$ & $65(25.7 \%)$ & $101(30.0 \%)$ & \\
\hline Obese, $n(\%)$ & $94(37.1 \%)$ & $91(27.1 \%)$ & \\
\hline \multicolumn{4}{|l|}{ Male (9-13 y) } \\
\hline$n$ & 73 & 86 & \\
\hline Age (years) & $10.9(1.4)$ & $10.9(1.5)$ & 1.000 \\
\hline $\mathrm{BMI}^{2}$ & & & 0.219 \\
\hline Underweight, $n(\%)$ & $3(4.6 \%)$ & $6(8.7 \%)$ & \\
\hline Normal, $n(\%)$ & $37(56.9 \%)$ & $46(66.7 \%)$ & \\
\hline Overweight, $n(\%)$ & $17(26.2 \%)$ & $14(20.3 \%)$ & \\
\hline Obese, $n(\%)$ & $8(12.3 \%)$ & $3(4.3 \%)$ & \\
\hline \multicolumn{4}{|l|}{ Female (4-8 y) } \\
\hline$n$ & 74 & 73 & \\
\hline Age (years) & $5.9(1.4)$ & $5.7(1.4)$ & 0.610 \\
\hline $\mathrm{BMI}^{2}$ & & & 0.270 \\
\hline Underweight, $n(\%)$ & $5(9.1 \%)$ & $1(1.7 \%)$ & \\
\hline Normal, $n(\%)$ & $40(72.7 \%)$ & $44(75.9 \%)$ & \\
\hline Overweight, $n(\%)$ & $6(10.9 \%)$ & $10(17.2 \%)$ & \\
\hline Obese, $n(\%)$ & $4(7.3 \%)$ & $3(5.2 \%)$ & \\
\hline \multicolumn{4}{|l|}{ SES data } \\
\hline IRSAD quintile & 1 & 3 & \\
\hline Equivalized disposable income (AUD) ${ }^{3}$ & AUD 399/week & AUD 902/week & \\
\hline Adjusted household income (AUD) ${ }^{4}$ & AUD 798/week & AUD 1804/week & \\
\hline
\end{tabular}

IRSAD, Index of Relative Socioeconomic Advantage and Disadvantage; SES, socioeconomic status. ${ }^{1}$ Data are mean (SD) unless otherwise indicated. ${ }^{2}$ BMI data and categories were taken directly from the NNPAS microdata. ${ }^{3}$ Sourced from the 2017-2018 Australian Survey of Income and Housing [38]. ${ }^{4}$ Equivalized disposable income (2017-2018) multiplied by the OECD adjustment factor of 2 (for a household of 4) [11]. ${ }^{5}$ For statistical significance, $p<0.005 ; p$-values derived using two sample t-tests for continuous data and the chi-squared statistic for categorical data.

\subsubsection{Diet Quality}

The diet quality of modelled adult diets was examined using the validated Healthy Eating Index for Australian Adults (HEIFA-2013) [40]. The HEIFA-13 was calculated based on an 11-component system of five food groups (vegetables, fruits, cereals and grains, dairy and dairy alternatives, and meat and meat alternatives), three negative nutrients (fats, added sugars, and sodium), water intake, and alcohol intake. Both current and healthier modelled diets were given the maximum (healthiest) score for Component 7 (water) and Component 11 (alcohol), as these foods were excluded from the current study.

The Dietary Guidelines Index for Children and Adolescents (DGI-CA) was used to assess the diet quality of children's diets [41-43]. The DGI-CA was calculated based on 
11 components ( 5 core food groups; intake of wholegrain bread and reduced-fat dairy foods; intake of extra foods that are nutrient poor and high in fat, salt, and added sugars; healthy fats and oils; water; and diet variety). Both current and healthier modelled diets were given the maximum (healthiest) score for water (Component 6), as this food was excluded from the current study.

\subsection{Statistical Analyses}

Statistical analyses were performed using the $\mathrm{R}$ programming language (version 4.0.3, R Core Team, Vienna, Austria) [44], with extensive use of the tidyverse packages (R Studio, Boston, MA, USA) [45]. Mean (SD) was used to describe population, nutrition, and cost input data, and mean (SEM) was used to present dietary data produced from the substitution modelling protocol. The recommended serving size, as determined by the Australian Guide to Healthy Eating [39], was recorded.

Statistical significance, for comparison of nutrition and cost between diets, was obtained from a general linear model with SES, age-sex category, and their interaction as fixed factors. A linear combination of adult male + adult female + child male + child female was used to obtain values for a model 'household' of two parents and two children. Values of $p<0.005$ were taken to represent statistical significance, adjusted down from $p<0.05$ using a Bonferroni approach for multiple comparisons within groups of variables.

\section{Results}

3.1. Nutrient Density, Cost, and the Nutrient Density-to-Cost Ratio of Australian Food Categories

The nutrient density of each of the 57 food categories (defined by NRF9.3/100 kcal), was plotted as a function of cost (AUD/100 kcal), as shown in Figure 1a, in which core and discretionary food categories are shown separately on distinct sets of axes. Nutrient densities (per $100 \mathrm{kcal}$ ) ranged from -22.3 (processed meat, with cost at AUD 0.74 per $100 \mathrm{kcal}$ ) to 479.2 (green leafy vegetables, with cost at AUD 6.01 per $100 \mathrm{kcal}$ ). Green leafy vegetables, the highest nutrient density food category, was also the most expensive. The majority of food categories were clustered around a nutrient density score of less than 100/100 kcal and a cost less than AUD 1/100 kcal (Figure 1b). Processing levels were evenly distributed throughout all nutrient density and cost levels for core foods (left-hand axes), but there were no unprocessed food categories in discretionary foods (right-hand axes).

The nutrient density score (NRF9.3/100 kcal) for the top quartile of nutrient dense, lowcost food categories ranged from 12.9 ((SD 4.6) rice, grains and flours) to 443.0 ((SD 160.6) other vegetables); the only discretionary food category included was processed potatoes (e.g., commercial oven potato fries, 37.3 (SD 4.9)) (Table 3). Rice, grains, and flours were the most affordable food category (0.04 [SD: 0.0] AUD/100 kcal), and other vegetables were the most expensive (2.2 (SD 1.4) AUD/100 kcal). Dried fruit had the lowest nutrient density-tocost ratio within the top quartile of nutrient dense, low-cost food categories (171.0 (SD 80.1)) and fruit juice had the highest (650.1 (SD 318.9)) (Table 3), followed by orange and yellow vegetables, processed potatoes, and rice, grains, and flours. No food categories from 'other foods' were in the top quartile (Supplementary Table S3. The difference in scores between the top (first) and second nutrient density-to-cost ratio quartiles was small $(\leq 100)$ for fruit, cereals and grains, and dairy and dairy alternatives (Supplementary Table S3). The top quartile of nutrient density-to-cost ratio contained $54 \%$ unprocessed, $13 \%$ processed, and $33 \%$ ultra-processed food categories. 


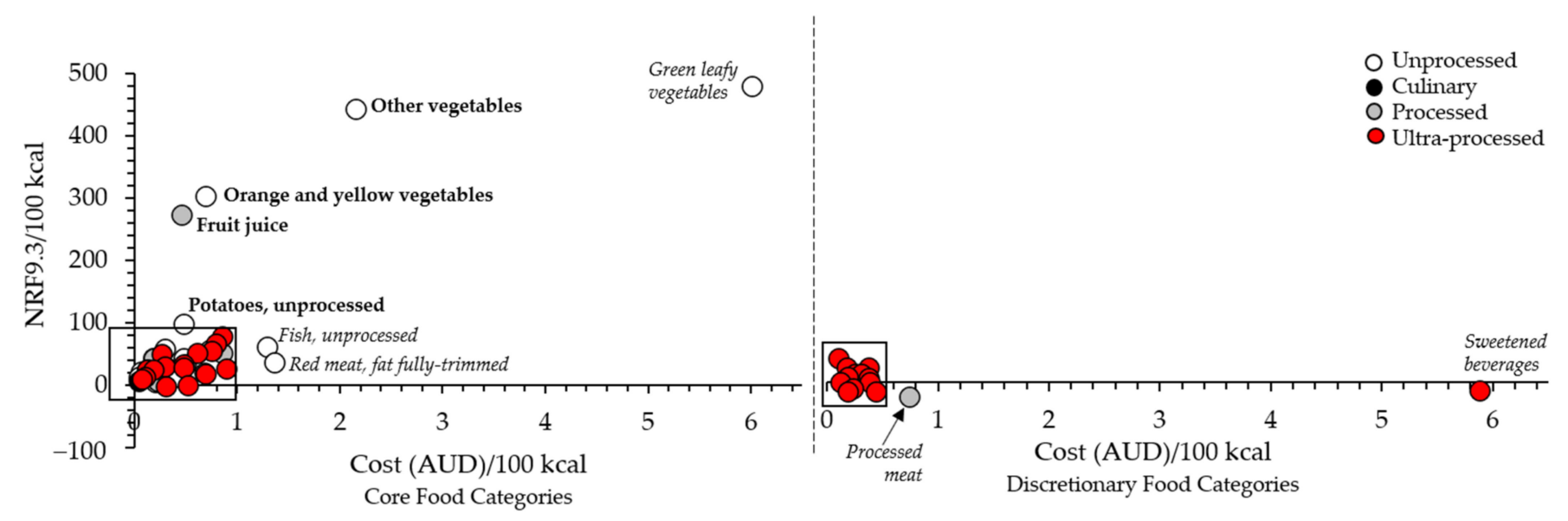

(a)

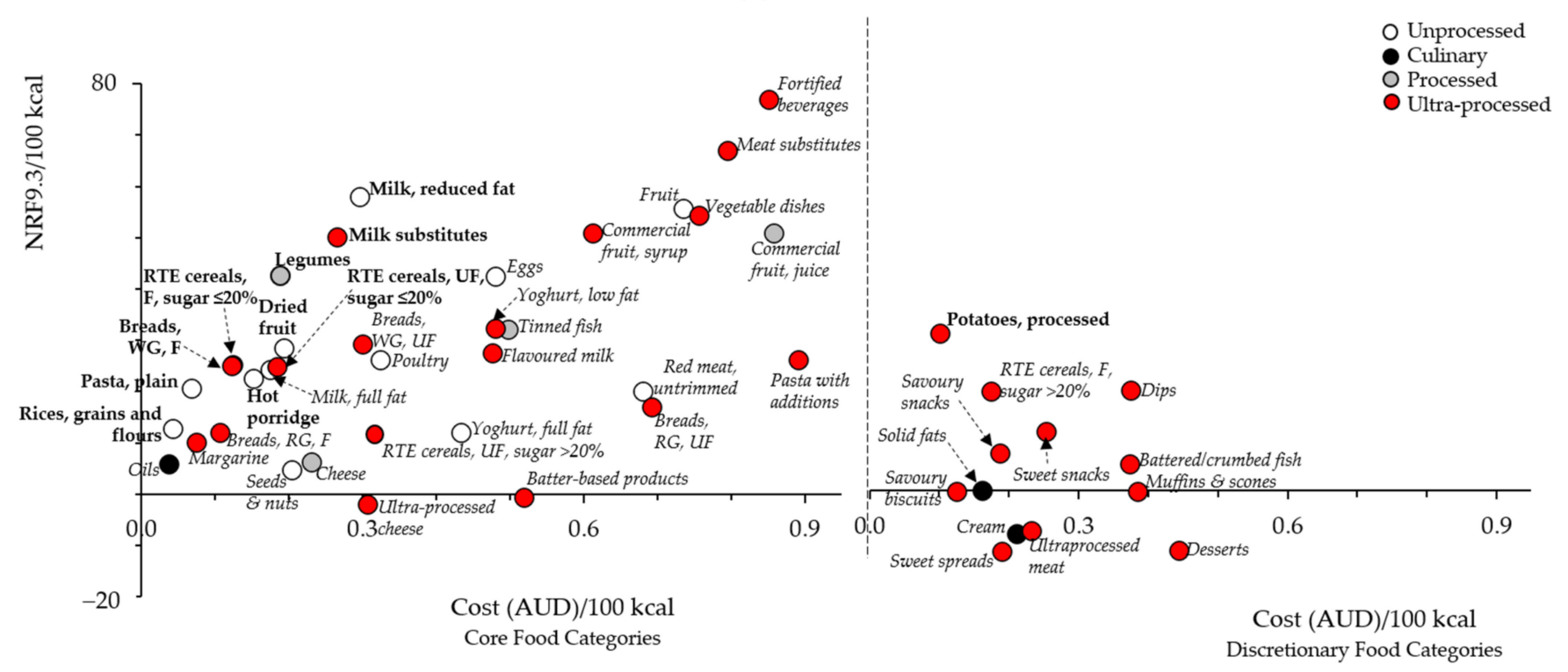

(b)

Figure 1. Nutrient density (NRF9.3) per 100 kcal vs. cost (AUD per 100 kcal) for the 57 food categories. (a) Full graph illustrating the relationship between nutrient density and cost for all 57 food categories, separated as core or discretionary food categories. The majority of food categories are clustered with an NRF9.3/100 kcal less than 80 and a cost (AUD)/100 kcal) less than AUD 0.9 (boxed areas). The food categories in the highest quartile of the nutrient density-to-cost ratio are shown in bold, food categories in Quartiles 2-4 are in italics; (b) enlargement of the clustered food categories contained within the boxes in Figure 1a for each core and discretionary food category. The food categories appearing in the highest quartile of the nutrient density-to-cost ratio are shown in bold, and food categories in Quartiles 2-4 are in italics. Figure abbreviations: F, fortified; RTE, ready to eat; RG, refined grain; UF, unfortified; WG, wholegrain.

\subsection{The Current Australian Diet}

All members in each household reported a low intake across all core food groups, except for females aged 4-8 years from medium SES households who achieved the recommended two servings of fruit per day (Table 4). Discretionary servings exceeded the maximum of two servings per day for all participants. All diets were high in saturated fat and sodium, and low in dietary fiber, Vitamin E, and potassium. 
Table 3. Details for the top quartile of nutrient dense, low-cost food categories, including nutrient density/100 kcal, cost $/ 100 \mathrm{kcal}$, the nutrient density to cost ratio, and NOVA processing classification.

\begin{tabular}{|c|c|c|c|c|}
\hline Food Categories ${ }^{1}$ & $\begin{array}{c}\text { NRF9.3/ } \\
100 \text { kcal }^{2}\end{array}$ & $\begin{array}{c}\text { AUD/ } \\
100 \text { kcal }\end{array}$ & $\begin{array}{l}\text { Nutrient Density- } \\
\text { to-Cost Ratio }^{3}\end{array}$ & $\begin{array}{l}\text { NOVA Processing } \\
\text { Classification }\end{array}$ \\
\hline \multicolumn{5}{|l|}{ Vegetables } \\
\hline Orange/yellow vegetables & $302.2(126.0)$ & $0.7(0.1)$ & $492.3(304.5)$ & Unprocessed \\
\hline Other vegetables & $443.0(160.6)$ & $2.2(1.4)$ & $293.4(171.9)$ & Unprocessed \\
\hline Potatoes, unprocessed & $97.1(4.6)$ & $0.5(0.1)$ & $217.0(73.2)$ & Unprocessed \\
\hline \multicolumn{5}{|l|}{ Fruit } \\
\hline Fruit juice & $273.7(124.8)$ & $0.5(0.2)$ & $650.1(318.9)$ & Processed \\
\hline Dried fruit & $28.6(9.0)$ & $0.2(0.1)$ & $171.0(80.1)$ & Unprocessed \\
\hline \multicolumn{5}{|l|}{ Cereals and grain foods } \\
\hline Rice, grains and flours & $12.9(4.6)$ & $0.04(0.0)$ & $348.3(196.5)$ & Unprocessed \\
\hline Pasta and noodles, plain & $20.7(9.0)$ & $0.1(0.0)$ & $304.6(43.6)$ & Unprocessed \\
\hline Hot porridge & $22.6(7.6)$ & $0.2(0.1)$ & $290.9(219.8)$ & Unprocessed \\
\hline Breads, wholegrain and fortified & $25.1(3.1)$ & $0.1(0.0)$ & $213.0(57.7)$ & Ultra-processed \\
\hline RTE breakfast cereals, fortified, sugars $\leq 20 \mathrm{~g} / 100 \mathrm{~g}$ & $25.3(26.4)$ & $0.1(0.0)$ & $200.1(178.4)$ & Ultra-processed \\
\hline RTE breakfast cereals, unfortified, sugars $\leq 20 \mathrm{~g} / 100 \mathrm{~g}$ & $24.9(10.8)$ & $0.2(0.1)$ & $176.1(117.8)$ & Ultra-processed \\
\hline Dairy milk alternatives & $50.1(30.7)$ & $0.3(0.1)$ & $214.1(161.3)$ & Ultra-processed \\
\hline Dairy milk, reduced fat or skim & $58.0(13.0)$ & $0.3(0.1)$ & $209.9(79.0)$ & Unprocessed \\
\hline \multicolumn{5}{|l|}{ Meat and alternatives } \\
\hline Legumes and legume dishes & $42.6(5.6)$ & $0.2(0.0)$ & $231.4(50.0)$ & Processed \\
\hline \multicolumn{5}{|l|}{ Discretionary foods } \\
\hline Potatoes, processed & $37.3(4.9)$ & $0.1(0.0)$ & $403.5(109.3)$ & Ultra-processed \\
\hline
\end{tabular}

${ }^{1}$ All data are mean (SD). ${ }^{2}$ The NRF9.3 was calculated as described in references [16,36]. Food categories are defined as follows: 'potatoes, unprocessed', baked, boiled, grilled, or BBQ'd potatoes; 'other vegetables', all vegetables not otherwise categorized as potatoes, leafy green vegetables or orange/yellow vegetables; 'breads, wholegrain and fortified', commercial wholegrain breads fortified with iodine, Vitamin B1 and folic acid; 'RTE breakfast cereals, fortified, sugars $\leq 20 \mathrm{~g} / 100 \mathrm{~g}$ ', ready to eat breakfast cereals fortified with Vitamin B1, B2, B3, folic acid and iron, mean sugars content $10.5 \mathrm{~g} / 100 \mathrm{~g}$; 'dairy milk alternatives', commercial soy and rice-based milks; 'potatoes, processed', commercial oven-fries, wedges and hash-browns. ${ }^{3}$ The nutrient density-to-cost ratio was calculated as the mean of the ratios for the representative foods chosen in each food category.

Table 4. The current Australian diet for each member of the reference household, for both low and medium SES positions.

\begin{tabular}{|c|c|c|c|c|c|c|c|c|c|c|}
\hline \multirow[b]{2}{*}{ Current Diet ${ }^{1}$} & \multicolumn{5}{|c|}{ Low SES Household } & \multicolumn{5}{|c|}{ Medium SES Household } \\
\hline & $\begin{array}{c}\text { Male } \\
31-50 \text { y }\end{array}$ & $\begin{array}{l}\text { Female } \\
31-50 \text { y }\end{array}$ & $\begin{array}{l}\text { Male } \\
9-13 y\end{array}$ & $\begin{array}{c}\text { Female } \\
4-8 y\end{array}$ & Total & $\begin{array}{c}\text { Male } \\
31-50 \text { y }\end{array}$ & $\begin{array}{l}\text { Female } \\
31-50 \text { y }\end{array}$ & $\begin{array}{l}\text { Male } \\
9-13 \text { y }\end{array}$ & $\begin{array}{c}\text { Female } \\
4-8 \text { y }\end{array}$ & Total \\
\hline$n$ & 281 & 301 & 73 & 74 & & 324 & 408 & 86 & 73 & \\
\hline $\begin{array}{l}\text { Diet cost and } \\
\text { affordability }\end{array}$ & & & & & & & & & & \\
\hline $\begin{array}{l}\text { Cost of diet per week } \\
\text { (AUD) }\end{array}$ & $\begin{array}{l}36.8 \\
(1.2)\end{array}$ & $\begin{array}{l}28.9 \\
(1.0)\end{array}$ & $\begin{array}{l}35.3 \\
(1.9)\end{array}$ & $\begin{array}{l}28.7 \\
(1.5)\end{array}$ & $\begin{array}{l}129.7 \\
(2.9)\end{array}$ & $\begin{array}{l}39.2 \\
(1.2)\end{array}$ & $\begin{array}{l}32.7 \\
(0.9)\end{array}$ & $\begin{array}{l}38.2 \\
(2.0)\end{array}$ & $\begin{array}{l}30.8 \\
(1.5)\end{array}$ & $\begin{array}{l}140.9 \\
(2.9)\end{array}$ \\
\hline Diet affordability (\%) ${ }^{2}$ & - & - & - & - & 16.3 & - & - & - & - & 7.8 \\
\hline Total energy (kcal/day) & $\begin{array}{l}1715.8 \\
(61.7)\end{array}$ & $\begin{array}{l}1238.7 \\
(38.8)\end{array}$ & $\begin{array}{l}1697.1 \\
(89.7)\end{array}$ & $\begin{array}{l}1495.0 \\
(74.4)\end{array}$ & $\begin{array}{l}6146.6 \\
(137.5)\end{array}$ & $\begin{array}{l}1680.3 \\
(45.7)\end{array}$ & $\begin{array}{l}1378.7 \\
(35.1)\end{array}$ & $\begin{array}{l}1868.8 \\
(80.9)\end{array}$ & $\begin{array}{c}1430.8 \\
(74.2)\end{array}$ & $\begin{array}{l}6358.6 \\
(124.0)\end{array}$ \\
\hline \multicolumn{11}{|l|}{$\begin{array}{l}\text { Food groups } \\
\left(\text { servings/day }{ }^{3} \text { ) }\right.\end{array}$} \\
\hline Vegetables & $\begin{array}{c}1.8 \\
(0.2)\end{array}$ & $\begin{array}{c}1.6 \\
(0.1)\end{array}$ & $\begin{array}{c}1.1 \\
(0.2)\end{array}$ & $\begin{array}{c}0.6 \\
(0.1)\end{array}$ & $\begin{array}{c}5.2 \\
(0.3)\end{array}$ & $\begin{array}{c}1.9 \\
(0.1)\end{array}$ & $\begin{array}{l}1.7 \\
(0.1)\end{array}$ & $\begin{array}{c}0.8 \\
(0.2)\end{array}$ & $\begin{array}{l}1.0 \\
(0.2)\end{array}$ & $\begin{array}{c}5.4 \\
(0.3)\end{array}$ \\
\hline Fruit & $\begin{array}{l}1.2 \\
(0.1)\end{array}$ & $\begin{array}{l}1.2 \\
(0.1)\end{array}$ & $\begin{array}{c}1.6 \\
(0.2)\end{array}$ & $\begin{array}{c}1.4 \\
(0.2)\end{array}$ & $\begin{array}{c}5.5 \\
(0.3)\end{array}$ & $\begin{array}{l}1.3 \\
(0.1)\end{array}$ & $\begin{array}{l}1.2 \\
(0.1)\end{array}$ & $\begin{array}{c}1.7 \\
(0.2)\end{array}$ & $\begin{array}{c}2.0 \\
(0.2)\end{array}$ & $\begin{array}{c}6.2 \\
(0.3)\end{array}$ \\
\hline Grain (cereal) foods & $\begin{array}{c}3.3 \\
(0.2)\end{array}$ & $\begin{array}{c}2.4 \\
(0.1)\end{array}$ & $\begin{array}{c}3.0 \\
(0.3)\end{array}$ & $\begin{array}{l}2.8 \\
(0.2)\end{array}$ & $\begin{array}{l}11.5 \\
(0.4)\end{array}$ & $\begin{array}{c}3.4 \\
(0.2)\end{array}$ & $\begin{array}{c}2.5 \\
(0.1)\end{array}$ & $\begin{array}{l}3.6 \\
(0.2)\end{array}$ & $\begin{array}{l}2.7 \\
(0.2)\end{array}$ & $\begin{array}{l}12.2 \\
(0.4)\end{array}$ \\
\hline $\begin{array}{l}\text { Lean meats and } \\
\text { alternatives }\end{array}$ & $\begin{array}{c}1.3 \\
(0.1)\end{array}$ & $\begin{array}{c}0.9 \\
(0.1)\end{array}$ & $\begin{array}{c}0.7 \\
(0.1)\end{array}$ & $\begin{array}{c}0.5 \\
(0.1)\end{array}$ & $\begin{array}{c}3.4 \\
(0.2)\end{array}$ & $\begin{array}{l}1.4 \\
(0.1)\end{array}$ & $\begin{array}{c}1.1 \\
(0.1)\end{array}$ & $\begin{array}{c}0.7 \\
(0.1)\end{array}$ & $\begin{array}{c}0.3 \\
(0.1)\end{array}$ & $\begin{array}{c}3.5 \\
(0.2)\end{array}$ \\
\hline $\begin{array}{l}\text { Dairy and dairy } \\
\text { alternatives }\end{array}$ & $\begin{array}{l}1.4 \\
(0.1)\end{array}$ & $\begin{array}{l}1.1 \\
(0.1)\end{array}$ & $\begin{array}{l}1.6 \\
(0.2)\end{array}$ & $\begin{array}{l}1.6 \\
(0.1)\end{array}$ & $\begin{array}{c}5.7 \\
(0.3)\end{array}$ & $\begin{array}{l}1.3 \\
(0.1)\end{array}$ & $\begin{array}{l}1.1 \\
(0.1)\end{array}$ & $\begin{array}{l}1.7 \\
(0.2)\end{array}$ & $\begin{array}{l}1.5 \\
(0.2)\end{array}$ & $\begin{array}{c}5.7 \\
(0.3)\end{array}$ \\
\hline Discretionary foods & $\begin{array}{c}5.7 \\
(0.3)\end{array}$ & $\begin{array}{c}4.0 \\
(0.2)\end{array}$ & $\begin{array}{c}5.9 \\
(0.5)\end{array}$ & $\begin{array}{c}4.3 \\
(0.4)\end{array}$ & $\begin{array}{l}19.9 \\
(0.7)\end{array}$ & $\begin{array}{l}5.8 \\
(0.3)\end{array}$ & $\begin{array}{c}4.3 \\
(0.2)\end{array}$ & $\begin{array}{l}7.0 \\
(0.5)\end{array}$ & $\begin{array}{l}4.6 \\
(0.3)\end{array}$ & $\begin{array}{l}21.6 \\
(0.7)\end{array}$ \\
\hline
\end{tabular}


Table 4. Cont.

\begin{tabular}{|c|c|c|c|c|c|c|c|c|c|c|}
\hline \multirow[b]{2}{*}{ Current Diet ${ }^{1}$} & \multicolumn{5}{|c|}{ Low SES Household } & \multicolumn{5}{|c|}{ Medium SES Household } \\
\hline & $\begin{array}{c}\text { Male } \\
31-50 \text { y }\end{array}$ & $\begin{array}{l}\text { Female } \\
31-50 \text { y }\end{array}$ & $\begin{array}{l}\text { Male } \\
9-13 \text { y }\end{array}$ & $\begin{array}{c}\text { Female } \\
4-8 y\end{array}$ & Total & $\begin{array}{l}\text { Male } \\
31-50 \text { y }\end{array}$ & $\begin{array}{l}\text { Female } \\
31-50 y\end{array}$ & $\begin{array}{l}\text { Male } \\
9-13 \text { y }\end{array}$ & $\begin{array}{c}\text { Female } \\
4-8 y\end{array}$ & Total \\
\hline \multicolumn{11}{|l|}{$\begin{array}{l}\text { Macronutrients (\% of } \\
\text { energy) }\end{array}$} \\
\hline Protein & $\begin{array}{l}12.9 \\
(0.3)\end{array}$ & $\begin{array}{l}13.0 \\
(0.3)\end{array}$ & $\begin{array}{l}12.0 \\
(0.5)\end{array}$ & $\begin{array}{l}11.4 \\
(0.4)\end{array}$ & $\begin{array}{l}12.7 \\
(0.2)\end{array}$ & $\begin{array}{l}13.7 \\
(0.3)\end{array}$ & $\begin{array}{l}13.2 \\
(0.3)\end{array}$ & $\begin{array}{l}11.3 \\
(0.3)\end{array}$ & $\begin{array}{l}11.0 \\
(0.3)\end{array}$ & $\begin{array}{l}13.0 \\
(0.2)\end{array}$ \\
\hline Total fat & $\begin{array}{l}40.8 \\
(0.9)\end{array}$ & $\begin{array}{l}41.7 \\
(0.8)\end{array}$ & $\begin{array}{l}39.6 \\
(1.4)\end{array}$ & $\begin{array}{l}41.5 \\
(1.4)\end{array}$ & $\begin{array}{l}41.1 \\
(0.5)\end{array}$ & $\begin{array}{l}39.6 \\
(0.7)\end{array}$ & $\begin{array}{l}41.8 \\
(0.7)\end{array}$ & $\begin{array}{l}40.2 \\
(1.3)\end{array}$ & $\begin{array}{l}43.5 \\
(1.3)\end{array}$ & $\begin{array}{l}41.0 \\
(0.5)\end{array}$ \\
\hline Saturated fat & $\begin{array}{l}15.7 \\
(0.5)\end{array}$ & $\begin{array}{l}16.4 \\
(0.5)\end{array}$ & $\begin{array}{l}15.7 \\
(0.8)\end{array}$ & $\begin{array}{l}16.2 \\
(0.7)\end{array}$ & $\begin{array}{r}16.1 \\
(0.3)\end{array}$ & $\begin{array}{l}15.3 \\
(0.4)\end{array}$ & $\begin{array}{l}16.5 \\
(0.4)\end{array}$ & $\begin{array}{l}15.9 \\
(0.7)\end{array}$ & $\begin{array}{l}17.9 \\
(0.8)\end{array}$ & $\begin{array}{c}16.1 \\
(0.3)\end{array}$ \\
\hline Monounsaturated fat & $\begin{array}{l}16.3 \\
(0.4)\end{array}$ & $\begin{array}{l}16.3 \\
(0.4)\end{array}$ & $\begin{array}{l}15.7 \\
(0.7)\end{array}$ & $\begin{array}{l}16.4 \\
(0.7)\end{array}$ & $\begin{array}{c}16.2 \\
(0.3)\end{array}$ & $\begin{array}{l}15.8 \\
(0.3)\end{array}$ & $\begin{array}{l}16.2 \\
(0.3)\end{array}$ & $\begin{array}{l}15.8 \\
(0.6)\end{array}$ & $\begin{array}{l}16.6 \\
(0.5)\end{array}$ & $\begin{array}{c}16.0 \\
(0.2)\end{array}$ \\
\hline Polyunsaturated fat & $\begin{array}{c}5.8 \\
(0.2)\end{array}$ & $\begin{array}{c}6.1 \\
(0.2)\end{array}$ & $\begin{array}{c}5.3 \\
(0.3)\end{array}$ & $\begin{array}{c}6.0 \\
(0.4)\end{array}$ & $\begin{array}{c}5.9 \\
(0.1)\end{array}$ & $\begin{array}{c}5.7 \\
(0.2)\end{array}$ & $\begin{array}{c}6.1 \\
(0.2)\end{array}$ & $\begin{array}{c}5.5 \\
(0.3)\end{array}$ & $\begin{array}{c}5.8 \\
(0.3)\end{array}$ & $\begin{array}{c}5.9 \\
(0.1)\end{array}$ \\
\hline Total Carbohydrates & $\begin{array}{l}44.7 \\
(0.9)\end{array}$ & $\begin{array}{l}43.8 \\
(0.8)\end{array}$ & $\begin{array}{l}46.5 \\
(1.4)\end{array}$ & $\begin{array}{l}45.3 \\
(1.4)\end{array}$ & $\begin{array}{l}44.6 \\
(0.5)\end{array}$ & $\begin{array}{l}45.0 \\
(0.7)\end{array}$ & $\begin{array}{l}43.3 \\
(0.6)\end{array}$ & $\begin{array}{l}46.8 \\
(1.3)\end{array}$ & $\begin{array}{l}43.9 \\
(1.2)\end{array}$ & $\begin{array}{r}44.3 \\
(0.5)\end{array}$ \\
\hline Total sugars & $\begin{array}{l}22.1 \\
(0.9)\end{array}$ & $\begin{array}{l}22.4 \\
(0.7)\end{array}$ & $\begin{array}{l}16.8 \\
(1.0)\end{array}$ & $\begin{array}{l}17.0 \\
(0.9)\end{array}$ & $\begin{array}{l}21.2 \\
(0.4)\end{array}$ & $\begin{array}{l}22.2 \\
(0.7)\end{array}$ & $\begin{array}{l}20.4 \\
(0.5)\end{array}$ & $\begin{array}{l}17.8 \\
(0.8)\end{array}$ & $\begin{array}{l}17.7 \\
(0.9)\end{array}$ & $\begin{array}{l}20.6 \\
(0.4)\end{array}$ \\
\hline Added sugars & $\begin{array}{l}10.8 \\
(0.6)\end{array}$ & $\begin{array}{l}10.4 \\
(0.4)\end{array}$ & $\begin{array}{c}7.8 \\
(0.6)\end{array}$ & $\begin{array}{c}8.1 \\
(0.5)\end{array}$ & $\begin{array}{c}10.1 \\
(0.3)\end{array}$ & $\begin{array}{l}10.6 \\
(0.3)\end{array}$ & $\begin{array}{c}9.3 \\
(0.3)\end{array}$ & $\begin{array}{c}9.2 \\
(0.5)\end{array}$ & $\begin{array}{c}8.2 \\
(0.5)\end{array}$ & $\begin{array}{c}9.7 \\
(0.2)\end{array}$ \\
\hline Free sugars & $\begin{array}{l}15.2 \\
(0.8)\end{array}$ & $\begin{array}{l}15.0 \\
(0.6)\end{array}$ & $\begin{array}{l}10.2 \\
(0.9)\end{array}$ & $\begin{array}{l}10.5 \\
(0.8)\end{array}$ & $\begin{array}{c}14.1 \\
(0.4)\end{array}$ & $\begin{array}{l}15.2 \\
(0.5)\end{array}$ & $\begin{array}{l}12.8 \\
(0.5)\end{array}$ & $\begin{array}{l}11.5 \\
(0.7)\end{array}$ & $\begin{array}{l}10.5 \\
(0.7)\end{array}$ & $\begin{array}{r}13.4 \\
(0.3)\end{array}$ \\
\hline Starch & $\begin{array}{l}22.6 \\
(0.7)\end{array}$ & $\begin{array}{l}21.4 \\
(0.6)\end{array}$ & $\begin{array}{l}29.4 \\
(1.1)\end{array}$ & $\begin{array}{l}28.2 \\
(1.0)\end{array}$ & $\begin{array}{l}23.3 \\
(0.4)\end{array}$ & $\begin{array}{l}22.7 \\
(0.5)\end{array}$ & $\begin{array}{l}22.8 \\
(0.5)\end{array}$ & $\begin{array}{l}28.8 \\
(1.1)\end{array}$ & $\begin{array}{l}26.0 \\
(0.8)\end{array}$ & $\begin{array}{l}23.6 \\
(0.4)\end{array}$ \\
\hline Dietary fiber (g/day) & $\begin{array}{l}18.2 \\
(0.8)\end{array}$ & $\begin{array}{l}13.9 \\
(0.6)\end{array}$ & $\begin{array}{l}16.9 \\
(1.0)\end{array}$ & $\begin{array}{c}15.4 \\
(0.8)\end{array}$ & $\begin{array}{l}64.5 \\
(1.6)\end{array}$ & $\begin{array}{l}18.5 \\
(0.6)\end{array}$ & $\begin{array}{l}15.6 \\
(0.5)\end{array}$ & $\begin{array}{l}19.7 \\
(1.1)\end{array}$ & $\begin{array}{l}16.3 \\
(0.9)\end{array}$ & $\begin{array}{l}70.1 \\
(1.6)\end{array}$ \\
\hline
\end{tabular}

${ }^{1}$ All data are mean (SEM) per day, of all diets used for analysis, unless otherwise stated. ${ }^{2}$ Diet affordability is the mean diet cost per week expressed as a percentage of equivalized disposable income (as shown in Table 3 ). ${ }^{3}$ Servings per day were calculated on the basis of the servings sizes provided in the Australian Guide to Healthy Eating [39]. SES, socioconomic status.

Total food costs for medium SES households were AUD 140.90 per week as compared with AUD 129.70 per week for low SES households. Despite having higher total food costs, food was more affordable in the medium as compared with low SES households (Table 4).

\subsection{The Modelled Healthier, Low-Cost Australian Diet}

For both households, intakes of core food groups increased in the healthier diet as compared with the current diet $(p<0.001$ for all), despite an overall decrease in energy intake $(p<0.001)$, with the exception of fruit which showed no change (Table 5). As expected, due to the substitution modeling rules, discretionary intake was reduced to zero (Rule 1 , Supplementary Methods S2). The majority of macronutrient intakes improved for all members of both households. Total fat reduced by approximately $27 \%(p<0.001)$, saturated fat fell below the recommendations of less than $10 \%$ of energy intake to approximately $3.9 \%(p<0.001)$, and polyunsaturated fat intake increased to $12 \%$ of energy $(p<0.001)$. Although total sugars increased $(p<0.001)$, added sugars and free sugars both decreased to below $2 \%$ of energy $(p<0.001)$. Dietary fiber and vitamin A levels increased $(p<0.001)$ to meet reference values (Table 5 and Supplementary Table S4. However, protein intake decreased in the healthier diet for the medium SES household by $7 \%(p<0.001)$.

Concurrent with the overall improvement in nutritional composition of the healthier diets (Table 5) as compared with the current diets (Table 4), for all household members, there was a significant decrease of $25-27 \%$ in total food costs for both low and medium SES households (reduced to AUD 97.60 per week and AUD 102.60 per week, respectively, $p<0.001$ ), and a concomitant improvement in diet affordability. When matched for energy, the healthier diet remained lower in cost than the current diet for both low and medium socioeconomic households (data not shown). 
Table 5. The theoretical modelled healthier, low-cost diet for each member of the reference household, for both low and medium SES positions.

\begin{tabular}{|c|c|c|c|c|c|c|c|c|c|c|c|c|}
\hline \multirow{2}{*}{$\begin{array}{l}\text { Healthier, Low-Cost } \\
\text { Modelled Diet }^{1}\end{array}$} & \multicolumn{5}{|c|}{ Low SES Household } & \multicolumn{5}{|c|}{ Medium SES Household } & \multicolumn{2}{|c|}{$\begin{array}{l}\text { Current vs. Healthier Diets } \\
\qquad \text {-Value }^{3}\end{array}$} \\
\hline & $\begin{array}{c}\text { Male } \\
\text { 31-50 y }\end{array}$ & $\begin{array}{l}\text { Female } \\
31-50 y\end{array}$ & $\begin{array}{l}\text { Male } \\
9-13 \text { y }\end{array}$ & $\begin{array}{c}\text { Female } \\
4-8 y\end{array}$ & Total & $\begin{array}{c}\text { Male } \\
31-50 y\end{array}$ & $\begin{array}{l}\text { Female } \\
31-50 y\end{array}$ & $\begin{array}{l}\text { Male } \\
9-13 \text { y }\end{array}$ & $\begin{array}{c}\text { Female } \\
4-8 y\end{array}$ & Total & Low SES & Medium SES \\
\hline $\begin{array}{l}n \\
\text { Diet cost and } \\
\text { affordability }\end{array}$ & 281 & 301 & 73 & 74 & & 324 & 408 & 86 & 73 & & & \\
\hline $\begin{array}{l}\text { Cost of diet per week, } \\
\text { (AUD) } \\
\text { Diet affordability (\%) }{ }^{2}\end{array}$ & $\begin{array}{l}27.8 \\
(1.0)\end{array}$ & $\begin{array}{l}21.6 \\
(0.7)\end{array}$ & $\begin{array}{l}27.2 \\
(1.6)\end{array}$ & $\begin{array}{l}21.0 \\
(1.0)\end{array}$ & $\begin{array}{l}97.6 \\
(2.2) \\
12.2\end{array}$ & $\begin{array}{l}28.4 \\
(0.9)\end{array}$ & $\begin{array}{l}22.8 \\
(0.6)\end{array}$ & $\begin{array}{l}28.8 \\
(1.5)\end{array}$ & $\begin{array}{l}22.7 \\
(1.2)\end{array}$ & $\begin{array}{c}102.6 \\
(2.2) \\
5.7\end{array}$ & $<0.001$ & $<0.001$ \\
\hline $\begin{array}{l}\text { Total energy } \\
\text { (kcal/day) } \\
\text { Food groups } \\
\text { (servings/day }{ }^{4} \text { ) }\end{array}$ & $\begin{array}{l}1569.2 \\
(64.7)\end{array}$ & $\begin{array}{l}1108.1 \\
(42.8)\end{array}$ & $\begin{array}{l}1415.3 \\
(89.3)\end{array}$ & $\begin{array}{l}1210.3 \\
(66.5)\end{array}$ & $\begin{array}{l}5302.9 \\
(135.7)\end{array}$ & $\begin{array}{l}1519.8 \\
(49.8)\end{array}$ & $\begin{array}{l}1222.6 \\
(37.7)\end{array}$ & $\begin{array}{l}1543.7 \\
(77.2)\end{array}$ & $\begin{array}{l}1212.0 \\
(80.0)\end{array}$ & $\begin{array}{l}5498.1 \\
(127.5)\end{array}$ & $<0.001$ & $<0.001$ \\
\hline Vegetables & $\begin{array}{c}5.7 \\
(0.2)\end{array}$ & $\begin{array}{c}4.4 \\
(0.2)\end{array}$ & $\begin{array}{c}5.4 \\
(0.4)\end{array}$ & $\begin{array}{c}3.9 \\
(0.2)\end{array}$ & $\begin{array}{l}19.4 \\
(0.5)\end{array}$ & $\begin{array}{l}5.7 \\
(0.2)\end{array}$ & $\begin{array}{c}4.6 \\
(0.1)\end{array}$ & $\begin{array}{c}6.0 \\
(0.4)\end{array}$ & $\begin{array}{c}4.2 \\
(0.3)\end{array}$ & $\begin{array}{l}20.5 \\
(0.5)\end{array}$ & $<0.001$ & $<0.001$ \\
\hline Fruit & $\begin{array}{l}1.2 \\
(0.1)\end{array}$ & $\begin{array}{l}1.2 \\
(0.1)\end{array}$ & $\begin{array}{l}1.6 \\
(0.2)\end{array}$ & $\begin{array}{l}1.5 \\
(0.2)\end{array}$ & $\begin{array}{l}5.6 \\
(0.3)\end{array}$ & $\begin{array}{l}1.4 \\
(0.1)\end{array}$ & $\begin{array}{c}1.3 \\
(0.1)\end{array}$ & $\begin{array}{l}1.8 \\
(0.2)\end{array}$ & $\begin{array}{c}2.0 \\
(0.2)\end{array}$ & $\begin{array}{c}6.5 \\
(0.3)\end{array}$ & 0.068 & 0.001 \\
\hline Grain and cereal foods & $\begin{array}{l}3.5 \\
(0.2)\end{array}$ & $\begin{array}{c}2.5 \\
(0.1)\end{array}$ & $\begin{array}{l}3.2 \\
(0.3)\end{array}$ & $\begin{array}{l}2.9 \\
(0.2)\end{array}$ & $\begin{array}{l}12.1 \\
(0.4)\end{array}$ & $\begin{array}{l}3.7 \\
(0.2)\end{array}$ & $\begin{array}{l}2.6 \\
(0.1)\end{array}$ & $\begin{array}{l}3.8 \\
(0.2)\end{array}$ & $\begin{array}{l}2.8 \\
(0.2)\end{array}$ & $\begin{array}{l}12.8 \\
(0.4)\end{array}$ & $<0.001$ & $<0.001$ \\
\hline $\begin{array}{l}\text { Lean meats and } \\
\text { alternatives }\end{array}$ & $\begin{array}{c}2.3 \\
(0.2)\end{array}$ & $\begin{array}{l}1.5 \\
(0.1)\end{array}$ & $\begin{array}{l}1.6 \\
(0.2)\end{array}$ & $\begin{array}{l}1.2 \\
(0.2)\end{array}$ & $\begin{array}{c}6.5 \\
(0.4)\end{array}$ & $\begin{array}{c}2.3 \\
(0.1)\end{array}$ & $\begin{array}{l}1.8 \\
(0.1)\end{array}$ & $\begin{array}{l}1.5 \\
(0.2)\end{array}$ & $\begin{array}{l}1.3 \\
(0.2)\end{array}$ & $\begin{array}{c}7.0 \\
(0.3)\end{array}$ & $<0.001$ & $<0.001$ \\
\hline $\begin{array}{l}\text { Dairy and dairy } \\
\text { alternatives }\end{array}$ & $\begin{array}{l}1.9 \\
(0.1)\end{array}$ & $\begin{array}{l}1.4 \\
(0.1)\end{array}$ & $\begin{array}{c}2.0 \\
(0.2)\end{array}$ & $\begin{array}{l}1.7 \\
(0.2)\end{array}$ & $\begin{array}{l}7.0 \\
(0.3)\end{array}$ & $\begin{array}{l}1.8 \\
(0.1)\end{array}$ & $\begin{array}{l}1.6 \\
(0.1)\end{array}$ & $\begin{array}{l}2.1 \\
(0.2)\end{array}$ & $\begin{array}{l}1.7 \\
(0.2)\end{array}$ & $\begin{array}{c}7.2 \\
(0.3)\end{array}$ & $<0.001$ & $<0.001$ \\
\hline Discretionary foods & $\begin{array}{c}0.0 \\
(0.0)\end{array}$ & $\begin{array}{c}0.0 \\
(0.0)\end{array}$ & $\begin{array}{c}0.0 \\
(0.0)\end{array}$ & $\begin{array}{c}0.0 \\
(0.0)\end{array}$ & $\begin{array}{c}0.0 \\
(0.0)\end{array}$ & $\begin{array}{c}0.0 \\
(0.0)\end{array}$ & $\begin{array}{c}0.0 \\
(0.0)\end{array}$ & $\begin{array}{c}0.0 \\
(0.0)\end{array}$ & $\begin{array}{c}0.0 \\
(0.0)\end{array}$ & $\begin{array}{c}0.0 \\
(0.0)\end{array}$ & $<0.001$ & $<0.001$ \\
\hline $\begin{array}{l}\text { Macronutrients (\% of } \\
\text { energy) }\end{array}$ & & & & & & & & & & & & \\
\hline Protein & $\begin{array}{l}12.7 \\
(0.4)\end{array}$ & $\begin{array}{l}12.9 \\
(0.4)\end{array}$ & $\begin{array}{l}12.4 \\
(0.7)\end{array}$ & $\begin{array}{l}10.4 \\
(0.5)\end{array}$ & $\begin{array}{l}12.5 \\
(0.3)\end{array}$ & $\begin{array}{l}12.9 \\
(0.3)\end{array}$ & $\begin{array}{l}12.1 \\
(0.3)\end{array}$ & $\begin{array}{l}11.1 \\
(0.5)\end{array}$ & $\begin{array}{c}9.7 \\
(0.5)\end{array}$ & $\begin{array}{l}12.1 \\
(0.2)\end{array}$ & $<0.001$ & $<0.001$ \\
\hline Total fat & $\begin{array}{l}29.8 \\
(1.6)\end{array}$ & $\begin{array}{l}31.0 \\
(1.5)\end{array}$ & $\begin{array}{l}27.8 \\
(3.7)\end{array}$ & $\begin{array}{l}33.5 \\
(2.7)\end{array}$ & $\begin{array}{l}30.5 \\
(1.1)\end{array}$ & $\begin{array}{l}26.9 \\
(1.4)\end{array}$ & $\begin{array}{l}29.8 \\
(1.2)\end{array}$ & $\begin{array}{l}32.8 \\
(2.7)\end{array}$ & $\begin{array}{l}37.5 \\
(2.7)\end{array}$ & $\begin{array}{l}29.7 \\
(1.1)\end{array}$ & $<0.001$ & $<0.001$ \\
\hline Saturated fat & $\begin{array}{c}3.8 \\
(0.2)\end{array}$ & $\begin{array}{c}4.0 \\
(0.2)\end{array}$ & $\begin{array}{c}3.7 \\
(0.3)\end{array}$ & $\begin{array}{c}3.9 \\
(0.3)\end{array}$ & $\begin{array}{c}3.9 \\
(0.1)\end{array}$ & $\begin{array}{c}3.5 \\
(0.2)\end{array}$ & $\begin{array}{c}3.9 \\
(0.1)\end{array}$ & $\begin{array}{c}4.1 \\
(0.3)\end{array}$ & $\begin{array}{c}4.6 \\
(0.3)\end{array}$ & $\begin{array}{c}3.8 \\
(0.1)\end{array}$ & $<0.001$ & $<0.001$ \\
\hline Monounsaturated fat & $\begin{array}{l}11.6 \\
(0.7)\end{array}$ & $\begin{array}{l}12.1 \\
(0.7)\end{array}$ & $\begin{array}{l}10.8 \\
(1.2)\end{array}$ & $\begin{array}{l}13.1 \\
(1.2)\end{array}$ & $\begin{array}{l}11.9 \\
(0.5)\end{array}$ & $\begin{array}{l}10.4 \\
(0.6)\end{array}$ & $\begin{array}{l}11.6 \\
(0.5)\end{array}$ & $\begin{array}{l}12.9 \\
(1.1)\end{array}$ & $\begin{array}{l}14.9 \\
(1.2)\end{array}$ & $\begin{array}{l}11.6 \\
(0.5)\end{array}$ & $<0.001$ & $<0.001$ \\
\hline Polyunsaturated fat & $\begin{array}{l}12.1 \\
(0.7)\end{array}$ & $\begin{array}{l}12.6 \\
(0.7)\end{array}$ & $\begin{array}{l}11.2 \\
(1.2)\end{array}$ & $\begin{array}{l}14.2 \\
(1.2)\end{array}$ & $\begin{array}{l}12.4 \\
(0.5)\end{array}$ & $\begin{array}{l}10.9 \\
(0.6)\end{array}$ & $\begin{array}{l}12.0 \\
(0.5)\end{array}$ & $\begin{array}{l}13.5 \\
(1.2)\end{array}$ & $\begin{array}{l}15.5 \\
(1.2)\end{array}$ & $\begin{array}{l}12.0 \\
(0.5)\end{array}$ & 0.093 & 0.232 \\
\hline Total Carbohydrates & $\begin{array}{l}52.2 \\
(1.2)\end{array}$ & $\begin{array}{l}51.1 \\
(1.2)\end{array}$ & $\begin{array}{l}55.0 \\
(2.1)\end{array}$ & $\begin{array}{l}51.8 \\
(2.1)\end{array}$ & $\begin{array}{l}52.0 \\
(0.9)\end{array}$ & $\begin{array}{l}54.6 \\
(1.1)\end{array}$ & $\begin{array}{l}53.1 \\
(1.0)\end{array}$ & $\begin{array}{l}51.6 \\
(2.1)\end{array}$ & $\begin{array}{l}48.8 \\
(2.1)\end{array}$ & $\begin{array}{l}53.1 \\
(0.8)\end{array}$ & 0.209 & 0.118 \\
\hline Total sugars & $\begin{array}{l}21.1 \\
(1.0)\end{array}$ & $\begin{array}{l}23.2 \\
(0.9)\end{array}$ & $\begin{array}{l}24.3 \\
(1.6)\end{array}$ & $\begin{array}{l}22.0 \\
(1.5)\end{array}$ & $\begin{array}{l}22.4 \\
(0.6)\end{array}$ & $\begin{array}{l}22.4 \\
(0.9)\end{array}$ & $\begin{array}{l}23.9 \\
(0.8)\end{array}$ & $\begin{array}{l}20.2 \\
(1.2)\end{array}$ & $\begin{array}{l}23.1 \\
(1.4)\end{array}$ & $\begin{array}{l}23.0 \\
(0.6)\end{array}$ & $<0.001$ & $<0.001$ \\
\hline Added sugars & $\begin{array}{c}1.3 \\
(0.1)\end{array}$ & $\begin{array}{c}1.2 \\
(0.1)\end{array}$ & $\begin{array}{c}1.7 \\
(0.2)\end{array}$ & $\begin{array}{c}1.5 \\
(0.2)\end{array}$ & $\begin{array}{c}1.3 \\
(0.1)\end{array}$ & $\begin{array}{c}1.5 \\
(0.1)\end{array}$ & $\begin{array}{c}1.4 \\
(0.1)\end{array}$ & $\begin{array}{c}1.8 \\
(0.2)\end{array}$ & $\begin{array}{c}1.4 \\
(0.2)\end{array}$ & $\begin{array}{c}1.5 \\
(0.1)\end{array}$ & $<0.001$ & $<0.001$ \\
\hline Free sugars & $\begin{array}{c}1.6 \\
(0.1)\end{array}$ & $\begin{array}{c}1.6 \\
(0.1)\end{array}$ & $\begin{array}{c}2.6 \\
(0.4)\end{array}$ & $\begin{array}{c}2.1 \\
(0.2)\end{array}$ & $\begin{array}{c}1.8 \\
(0.1)\end{array}$ & $\begin{array}{c}2.3 \\
(0.3)\end{array}$ & $\begin{array}{c}1.8 \\
(0.1)\end{array}$ & $\begin{array}{c}2.5 \\
(0.2)\end{array}$ & $\begin{array}{c}1.9 \\
(0.2)\end{array}$ & $\begin{array}{c}2.1 \\
(0.1)\end{array}$ & $<0.001$ & $<0.001$ \\
\hline Starch & $\begin{array}{l}30.8 \\
(1.0)\end{array}$ & $\begin{array}{l}27.6 \\
(0.9)\end{array}$ & $\begin{array}{l}30.5 \\
(1.6)\end{array}$ & $\begin{array}{l}29.6 \\
(1.5)\end{array}$ & $\begin{array}{l}29.3 \\
(0.6)\end{array}$ & $\begin{array}{l}31.9 \\
(0.8)\end{array}$ & $\begin{array}{l}28.8 \\
(0.7)\end{array}$ & $\begin{array}{l}31.1 \\
(1.7)\end{array}$ & $\begin{array}{l}25.5 \\
(1.3)\end{array}$ & $\begin{array}{l}29.9 \\
(0.6)\end{array}$ & $<0.001$ & $<0.001$ \\
\hline Dietary fiber (g/day) & $\begin{array}{l}35.2 \\
(2.3)\end{array}$ & $\begin{array}{l}39.7 \\
(1.5)\end{array}$ & $\begin{array}{l}28.2 \\
(1.7)\end{array}$ & $\begin{array}{l}28.6 \\
(1.0)\end{array}$ & $\begin{array}{c}131.8 \\
(3.4)\end{array}$ & $\begin{array}{l}37.7 \\
(1.9)\end{array}$ & $\begin{array}{l}41.3 \\
(1.3)\end{array}$ & $\begin{array}{l}29.1 \\
(1.6)\end{array}$ & $\begin{array}{l}139.9 \\
(1.2)\end{array}$ & $\begin{array}{l}139.9 \\
(1.9)\end{array}$ & $<0.001$ & $<0.001$ \\
\hline
\end{tabular}

${ }^{1}$ All data are mean (SEM) per day, of all diets used for analysis, unless otherwise stated. ${ }^{2}$ Diet affordability is the mean diet cost per week expressed as a percentage of equivalized disposable income (as shown in Table 3). ${ }^{3} p$-values comparing diets from a general linear model for change in values with SES, age-sex group, and their interaction as fixed factors. For statistical significance, $p<0.005$. ${ }^{4}$ Servings per day were calculated based on the recommendations provided in the Australian Guide to Healthy Eating [39]. SES, socioeconomic status.

\subsection{Diet Quality of the Current and Healthier Modelled Diets}

The healthier, low-cost diet showed an improvement in diet quality over the current diet for all members of both households (adult diets ranged from 64.9 to $68.5 \mathrm{vs.} \mathrm{from} 43.7$ to 44.6 (Figure 2a); children's diets ranged from 76.8 to 80.6 vs. from 43.2 to $49.5 ; p<0.001$ for all (Figure 2b). Diet quality subscores improved for all members of both households $(<0.005$ for all), except for the fruit subscore (Supplementary Table S5). 


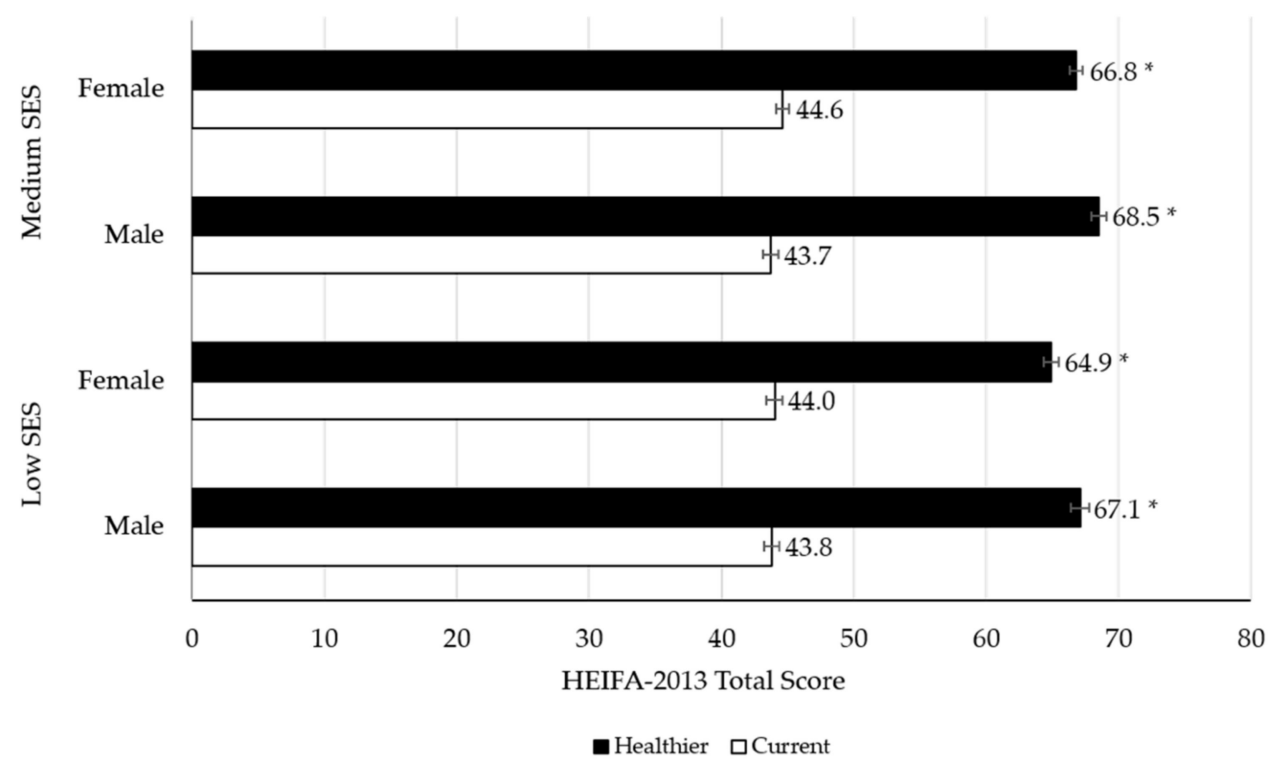

(a)

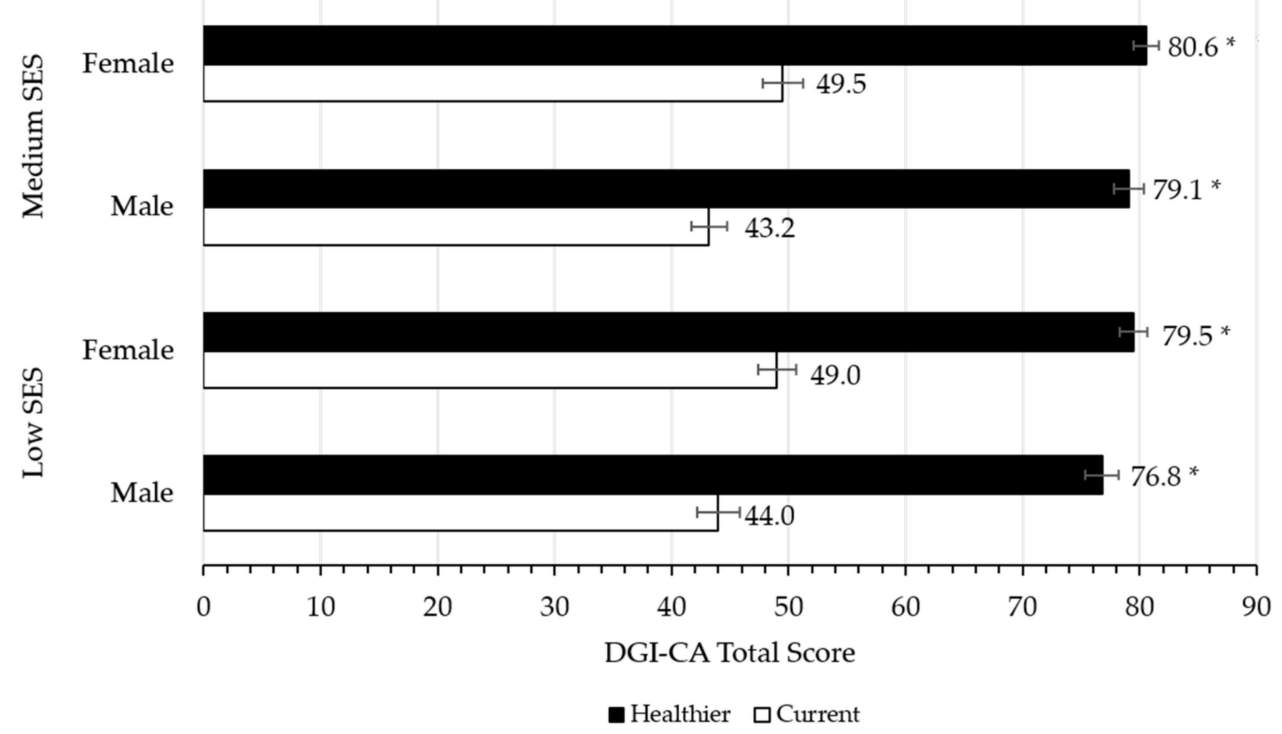

(b)

Figure 2. Diet quality of the current and healthier, low-cost diets, using validated diet quality indices. (a) HEIFA-2013 (Healthy Eating Index for Australian Adults) [40] assessment of the adult male and adult female current and healthier, low-cost diets, from each of the low and medium SES households; (b) DGI-CA (Dietary Guidelines Index for Children and Adolescents) [41-43] assessment of the male and female children's current and healthier, low-cost diets, from each of the low and medium SES households. Statistical significance is denoted by ${ }^{*} p<0.005$. Comparisons are between current and healthy diets within each group. SES, socioeconomic status.

3.5. Distribution of NOVA Processing Levels and Food Category Types throughout the Current and Healthier, Low-Cost Diets for Low and Medium SES Households

Current and healthier, low-cost diets contained foods from all NOVA processing categories (Table 6). Ultra-processed foods contributed approximately $60 \%$ of the current diet for both households, almost double that of unprocessed foods (approximately $32 \%$ ), and eight and half times that of processed foods (7\%). In the healthier, low-cost diets, unprocessed foods $(p<0.001$ for all) and processed foods increased $(p<0.001$ for all), and ultra-processed foods decreased ( $p<0.001$ for all), for both low and medium SES 
households. The increase in processed foods was attributed to legumes and legume dishes. Processed culinary foods also increased, attributed to unsaturated oils (Table 6). While ultraprocessed food categories decreased overall, the remaining $24-25 \%$ of ultra-processed food categories represented in the healthier diets were increased from current diets (commercial fruit in syrup, wholegrain breads, ready-to-eat cereals with $<20 \mathrm{~g}$ sugars $/ 100 \mathrm{~g}$, and dairy milk alternatives).

Table 6. Distribution of NOVA processing levels and food category types throughout the current and healthier diets for both low and medium SES households.

\begin{tabular}{|c|c|c|c|c|c|c|}
\hline \multirow[t]{2}{*}{ Category Distribution ${ }^{1}$} & \multicolumn{2}{|c|}{ Low SES Diets } & \multicolumn{2}{|c|}{ Medium SES Diets } & \multicolumn{2}{|c|}{$\begin{array}{l}\text { Current vs. Healthier Diets } \\
\qquad p \text {-Value }{ }^{2}\end{array}$} \\
\hline & Current & Healthier & Current & Healthier & Low SES & Medium SES \\
\hline$n$ & 729 & 729 & 891 & 891 & & \\
\hline Unprocessed & $31.3 \%(0.8)$ & $59.4 \%(0.7)$ & $32.2 \%(0.7)$ & $58.0 \%(0.6)$ & $<0.001$ & $<0.001$ \\
\hline Vegetables & $20.6 \%(1.1)$ & $66.3 \%(0.9)$ & $21.2 \%(0.9)$ & $67.1 \%(0.8)$ & $<0.001$ & $<0.001$ \\
\hline Fruit & $21.3 \%(1.1)$ & $13.7 \%(0.7)$ & $23.5 \%(1.0)$ & $14.4 \%(0.6)$ & $<0.001$ & $<0.001$ \\
\hline Pasta, rice and other grains & $9.6 \%(0.8)$ & $7.1 \%(0.6)$ & $8.7 \%(0.7)$ & $5.9 \%(0.5)$ & 0.010 & 0.001 \\
\hline Hot porridge & $1.2 \%(0.3)$ & $0.9 \%(0.2)$ & $2.3 \%(0.3)$ & $1.5 \%(0.2)$ & 0.405 & 0.042 \\
\hline Red meat, poultry and eggs & $14.8 \%(0.9)$ & $0.0 \%(0.0)$ & $17.8 \%(0.9)$ & $0.0 \%(0.0)$ & $<0.001$ & $<0.001$ \\
\hline Fish & $1.1 \%(0.3)$ & $0.0 \%(0.0)$ & $2.1 \%(0.3)$ & $0.0 \%(0.0)$ & $<0.001$ & $<0.001$ \\
\hline Nuts and seeds & $3.7 \%(0.5)$ & $0.0 \%(0.0)$ & $3.5 \%(0.4)$ & $0.0 \%(0.0)$ & $<0.001$ & $<0.001$ \\
\hline Full-fat milk & $18.9 \%(1.2)$ & $0.0 \%(0.0)$ & $12.4 \%(0.8)$ & $0.0 \%(0.0)$ & $<0.001$ & $<0.001$ \\
\hline Reduced fat milk & $7.3 \%(0.7)$ & $12.1 \%(0.6)$ & $7.2 \%(0.6)$ & $11.1 \%(0.5)$ & $<0.001$ & $<0.001$ \\
\hline Yoghurt, full fat & $1.5 \%(0.3)$ & $0.0 \%(0.0)$ & $1.3 \%(0.2)$ & $0.0 \%(0.0)$ & $<0.001$ & $<0.001$ \\
\hline Processed culinary & $1.6 \%(0.2)$ & $3.5 \%(0.3)$ & $1.6 \%(0.2)$ & $3.1 \%(0.2)$ & $<0.001$ & $<0.001$ \\
\hline Oils & $13.3 \%(3.0)$ & $100.0 \%(0.0)$ & $12.5 \%(2.4)$ & $100.0 \%(0.0)$ & $<0.001$ & $<0.001$ \\
\hline Discretionary fats & $86.7 \%(3.0)$ & $0.0 \%(0.0)$ & $87.5 \%(2.4)$ & $0.0 \%(0.0)$ & $<0.001$ & $<0.001$ \\
\hline Processed & $6.9 \%(0.4)$ & $12.7 \%(0.5)$ & $6.6 \%(0.3)$ & $14.3 \%(0.4)$ & $<0.001$ & $<0.001$ \\
\hline Fruit & $27.5 \%(2.2)$ & $11.5 \%(1.2)$ & $27.6 \%(1.9)$ & $9.7 \%(0.9)$ & $<0.001$ & $<0.001$ \\
\hline Tinned fish & $5.7 \%(1.1)$ & $0.0 \%(0.0)$ & $7.5 \%(1.1)$ & $0.0 \%(0.0)$ & $<0.001$ & $<0.001$ \\
\hline Cheese & $25.1 \%(2.0)$ & $0.0 \%(0.0)$ & $28.9 \%(1.9)$ & $0.0 \%(0.0)$ & $<0.001$ & $<0.001$ \\
\hline Legumes and legume dishes & $4.6 \%(1.0)$ & $88.5 \%(1.2)$ & $4.6 \%(0.9)$ & $90.3 \%(0.9)$ & $<0.001$ & $<0.001$ \\
\hline Discretionary & $37.1 \%(2.3)$ & $0.0 \%(0.0)$ & $31.4 \%(1.9)$ & $0.0 \%(0.0)$ & $<0.001$ & $<0.001$ \\
\hline Ultra-processed & $60.2 \%(0.9)$ & $24.4 \%(0.7)$ & $59.6 \%(0.7)$ & $24.7 \%(0.6)$ & $<0.001$ & $<0.001$ \\
\hline Vegetable dishes & $5.3 \%(0.6)$ & $0.0 \%(0.0)$ & $6.4 \%(0.5)$ & $0.0 \%(0.0)$ & $<0.001$ & $<0.001$ \\
\hline Commercial fruit, in syrup & $0.1 \%(0.1)$ & $2.3 \%(0.4)$ & $0.1 \%(0.0)$ & $2.5 \%(0.4)$ & $<0.001$ & $<0.001$ \\
\hline $\begin{array}{l}\text { Pasta and noodles, with } \\
\text { additions }\end{array}$ & $0.1 \%(0.0)$ & $0.0 \%(0.0)$ & $0.0 \%(0.0)$ & $0.0 \%(0.0)$ & 0.1681 & 0.158 \\
\hline Wholegrain breads & $7.6 \%(0.7)$ & $57.3 \%(1.5)$ & $7.5 \%(0.5)$ & $52.7 \%(1.3)$ & $<0.001$ & $<0.001$ \\
\hline Refined breads and flours & $16.6 \%(0.8)$ & $0.0 \%(0.0)$ & $14.4 \%(0.7)$ & $0.0 \%(0.0)$ & $<0.001$ & $<0.001$ \\
\hline $\begin{array}{l}\text { RTE breakfast cereals, } \leq 20 \mathrm{~g} \\
\text { sugars } / 100 \mathrm{~g}\end{array}$ & $6.0 \%(0.5)$ & $15.1 \%(1.1)$ & $7.8 \%(0.5)$ & $18.2 \%(1.0)$ & $<0.001$ & $<0.001$ \\
\hline Meat alternatives & $0.3 \%(0.2)$ & $0.0 \%(0.0)$ & $0.2 \%(0.1)$ & $0.0 \%(0.0)$ & 0.0891 & 0.129 \\
\hline $\begin{array}{l}\text { Milk, and milk-based } \\
\text { beverages }\end{array}$ & $2.9 \%(0.4)$ & $0.0 \%(0.0)$ & $2.7 \%(0.3)$ & $0.0 \%(0.0)$ & $<0.001$ & $<0.001$ \\
\hline Dairy milk alternatives & $0.4 \%(0.2)$ & $23.0 \%(1.2)$ & $0.6 \%(0.2)$ & $24.3 \%(1.1)$ & $<0.001$ & $<0.001$ \\
\hline Yoghurt, reduced fat & $0.8 \%(0.2)$ & $0.0 \%(0.0)$ & $1.1 \%(0.2)$ & $0.0 \%(0.0)$ & $<0.001$ & $<0.001$ \\
\hline Cheese & $1.9 \%(0.2)$ & $0.0 \%(0.0)$ & $1.3 \%(0.1)$ & $0.0 \%(0.0)$ & $<0.001$ & $<0.001$ \\
\hline $\begin{array}{l}\text { Margarines and } \\
\text { margarine-like spreads }\end{array}$ & $3.9 \%(0.3)$ & $2.3 \%(0.4)$ & $3.3 \%(0.2)$ & $2.3 \%(0.3)$ & $<0.001$ & 0.007 \\
\hline Discretionary & $54.1 \%(1.1)$ & $0.0 \%(0.0)$ & $54.6 \%(0.9)$ & $0.0 \%(0.0)$ & $<0.001$ & $<0.001$ \\
\hline
\end{tabular}

${ }^{1}$ All data are mean (SEM) percentage of all diets used for analysis. ${ }^{2}$ For statistical significance, $p<0.005$. Comparisons were calculated via unpaired Student's $t$-test. Food categories are defined as follows: 'discretionary fats' includes butter and cream; 'processed fruit' includes commercial fruit in juice and fruit juice; 'ultra-processed vegetable dishes', include commercially produced coleslaws, potato salad, and 'heat and eat' vegetable dishes; 'wholegrain breads and flours' include commercial wholegrain breads both unfortified and fortified with iodine, Vitamin B1, and folic acid; 'refined breads and flours' include commercial white breads both unfortified and fortified with iodine, Vitamin B1, and folic acid 'ready-to-eat (RTE) breakfast cereals, sugars $\leq 20 \mathrm{~g} / 100 \mathrm{~g}$ ' include ready-to-eat breakfast cereals both unfortified and fortified with Vitamin B1, B2, B3, folic acid, and iron, mean sugars content $11.9 \mathrm{~g} / 100 \mathrm{~g}$; 'meat alternatives' include commercially produced vegetarian sausages and vegetarian burgers; 'milk and milk-based beverages include fortified milk drinks and flavored milk; 'dairy milk alternatives' include commercially-produced rice and soy milk. 
The healthier, low-cost diets for both low and medium SES households, were higher in unprocessed vegetables $(66-67 \%$, from $21 \%)$, reduced fat milk $(11-12 \%$, from $7 \%$ ), unsaturated fats and oils (100\%, from 13\%), legumes and legume dishes $(89-90 \%$, from $5 \%)$, commercial fruit in syrup ( $2-3 \%$, from $0.1 \%$ ), wholegrain breads $(53-57 \%$, from $8 \%$ ), ready-to-eat breakfast cereals with $\leq 20 \mathrm{~g}$ sugars $/ 100 \mathrm{~g}$ (15-18\%, from $6-8 \%)$, and dairy milk alternatives (23-24\%, from $0.5 \%$ ) as compared with the current diet ( $p<0.001$ for all). There was a concomitant decrease (i.e., no inclusion in the healthier diet) in full-fat milk, cheese, whole fruit, refined breads and flour products, ultra-processed milk and milk-based beverages, and animal protein sources (red meat, poultry, eggs and fish) $(p<0.001$ for all).

\section{Discussion}

This was the first study to investigate the impact of substituting the current diet with foods that are low cost and nutritious, on the diet quality and affordability in Australia, with a secondary focus on food processing level. The findings suggest that the quality and affordability of the Australian diet can be improved concurrently, for both low and middle SES families, and that the low cost and nutritious diet includes foods of all processing levels, supporting hypotheses. In theoretical models, when foods in the Australian diet were replaced with nutrient dense, lower-cost alternatives, diet quality improved by $52 \%$ for adults and $71 \%$ for children across all households, while diet affordability improved by $25 \%$ and $27 \%$ for low and medium SES households, respectively. Cost-effective nutrient dense foods were identified across all processing levels, but were predominantly unprocessed (54\%, unprocessed potatoes, orange/yellow and other vegetables, and reduced fat dairy) and ultra-processed (33\%, fortified wholegrain bread and RTE cereals with less than $20 \mathrm{~g}$ sugars $/ 100 \mathrm{~g}$ ). Top quartile food categories with the highest nutrient density scores included foods from each of the five core food groups (vegetables, fruit, grains, meat/alternatives, and milk/alternatives).

The nutrient density-to-cost ratio was useful as it provided public health guidance for the selection of foods that improved nutrition at the most affordable cost [16,18]. Whilst findings of this study are pertinent for low and medium SES households, the reduction in food costs of $25-27 \%$ is also relevant for all SES households during times of economic instability, such as during the COVID-19 pandemic [9]. Although environmental sustainability was not considered in the current study, the results partly align with environmental sustainability-focused dietary modelling in New Zealand, where similarities were seen for changes in milk, potatoes, wholegrain flour, and legumes [17]. There is a need for follow-up research to translate this theoretical finding into practice to demonstrate that it is possible for low and medium SES families to eat a more nutritious diet, and at a lower cost, than their current diets.

The findings confirm that the top quartile of nutrient dense, low-cost food categories were across all core food groups, which suggests that nutrient dense, low-cost food choices are available to meet Australian dietary recommendations [39]. However, a number of nutrient dense food categories, that are culturally important and recommended in dietary guidelines as part of the core food groups, were removed during the modelling because their nutrient density-to-cost ratio did not fall within the top quartile, namely whole fresh fruit, unprocessed lean animal protein sources such as eggs, and leafy green vegetables. Whilst these three food categories are nutrient dense, they have a high cost in Australia, leading to a lower nutrient density-to-cost ratio. Therefore, fresh fruit was penalized by the diet quality indices, where fruit was the only subcategory that did not improve in the modelled diet. The lack of improvement in fruit servings could also be due to it being selected the least often to replace discretionary foods in the modelling due to the hierarchy chosen (Supplementary Methods S2). The costs of low energy-dense, leafy green vegetables were inflated in this study, due to the need to match food categories per $100 \mathrm{kcal}$. There was also misalignment with the dietary guidelines for discretionary processed potatoes, which featured in the top quartile of nutrient dense, low-cost food categories, as they provide some dietary fiber and vitamin C [26]. To correct this misalignment, they were 
omitted from the modelled healthier, low-cost diet as per protocol, as this category is purely discretionary.

It is well established that the majority of ultra-processed foods are energy dense and nutrient poor, and that there is a link between a high consumption of ultra-processed foods and negative health outcomes [46-49]. This relationship may further be exacerbated by the manufacturing process, the presence of non-nutritive additives, and the disruption of the food matrix [50,51]. Despite a substantial reduction in ultra-processed foods in the healthier, low-cost diets, a quarter of the diet remained to consist of ultra-processed foods. The finding that a subset of low-cost, ultra-processed foods can be classified as nutrient dense, such as the ultra-processed wholegrain breads and ready-to-eat breakfast cereals with $\leq 20 \mathrm{~g}$ sugars $/ 100 \mathrm{~g}$, suggests misalignment between the NOVA scheme and nutrient density $[19,20]$, especially when considering diet affordability. It has been proposed that lower SES groups readily select processed and ultra-processed foods for lower overall daily food costs, with a glass ceiling precluding their access to many unprocessed core foods [18]. The finding that nearly half of the foods in the modelled healthier, low-cost diet are processed and ultra-processed foods is consistent with previous research in the USA $[16,19]$. Consideration of the nutrient density and discretionary status of processed and ultra-processed foods is required to delineate the impact on diet quality and chronic disease, which may help to better inform public health messaging, consumer understanding of the classification, and clinical practice. As many populations and community groups rely on processing for food security [52], blanket dietary recommendations and public health strategies according to processing level alone could be reductionist and unrealistic. Specifically, the proportion of the category processed foods in the healthier, low-cost diets almost doubled. There is a need to revisit public health messaging about avoiding both processed and ultra-processed foods to ensure that we do not exclude low and middle SES families from accessing healthier more affordable core foods.

The current study has a number of strengths. The dietary data were nationally representative, and validated tools were used to assess nutrient density and diet quality. While previous Australian studies have used substitution modelling to examine nutritional interventions [53], or examine price differentials between current and healthy diets [12], this is the first study to use dietary substitution modelling to investigate the impact of nutrient dense, low-cost foods on parameters of both nutrition and cost. The assessment of food processing level in the modelled diets was also novel. Limitations of this study relate to the evidence that was used to inform the substitution modelling protocol. The generalizability of findings may be limited by the age of the dietary intake and nutrient composition data. Findings rely on the ranking of foods according to nutrient density, and thus the specific methods and tools used for its measurement. The NRF9.3 [36] was developed in the USA and selected as the preferred tool to measure nutrient density, rather than the Nutrient Profiling Scoring Criterion (NPSC) or the Health Star Rating (HSR) system, developed by Food Standards Australia New Zealand (FSANZ), and the Australasian governments, respectively. The NRF9.3 is a validated nutrient density tool, which has been used previously to compare the nutrient density of foods and assess the relationship nutrient density and cost $[16,19,20,36]$. However, it excludes some micronutrients, including all B-group vitamins, and it is important to consider that other nutrient density calculations may rank food categories differently as compared with the method used in this study. The lower cost of the healthier, low-cost diet may be partially due to it being lower in total energy; however, when matched for energy, the healthier, low-cost diet remained lower in cost than the current diet. The results are strengthened by similarities in the total number of servings per food category in both the current and healthier, low-cost diets, which confirms there were no differences in food volume. This study provides a theoretical proof-of-concept, and may not be translatable to individual dietary advice, particularly, due to the exclusion of mixed dishes in the modelling. It was not designed to model the composition of a nutritionally complete low-cost healthy diet, as this was outside the scope of this study. There is a need for research which embraces the complexity of the whole diet (e.g., including mixed dishes, 
take-away foods, and alcohol); and to examine whether individual foods in the top quartile of the nutrient density-to-cost ratio can be used to create a diet that meets national dietary recommendations.

\section{Conclusions}

This study provides evidence that nutrient dense, low-cost core foods can increase the quality and affordability of the Australian diet for both low and medium SES households. The nutrient dense, low-cost core foods were predominantly unprocessed and ultra-processed foods, which suggests that some non-discretionary ultra-processed foods may provide a beneficial source of nutrition when consumed within national dietary guideline recommendations. Future studies are needed to examine findings in other vulnerable groups, and to determine if foods can be modelled to meet national dietary recommendations.

Supplementary Materials: The following are available online at https:/ /www.mdpi.com/article/10 .3390 /ijerph18115771/s1. Table S1: Details and descriptions of all food categories, including all 8-digit codes included in each food category, Methods S1: The full calculation of NRF9.3, adapted for the Australian Nutrient Reference Values, Table S2: Reference values from the NRF9.3 and corresponding Australian Nutrient Reference Values used in the current study, Methods S2: Rules used to develop the substitution modelling protocol, Table S3: Nutrient density and NOVA processing level of all 57 food categories, Table S4: Micronutrient analysis of the current and healthier, low-cost diets for each member of both low and medium socioeconomic households, Table S5: Individual component scores for the HEIFA-2013 and DGI-CA, for each member of both low and medium SES households.

Author Contributions: C.S., M.B., K.A., S.M., T.C., and F.F.-M. conceived and designed the study; C.S., M.B., A.R., and T.K. executed the methods and analyzed the data; T.K. and P.P. carried out the substitution modelling and statistics; C.S. and M.B. wrote the paper; S.M. and F.F.-M. guided the methodological approach. All authors critically revised the manuscript. All authors have read and agreed to the published version of the manuscript.

Funding: This research was funded by a research grant from Kellogg Australia. Kellogg Australia contributed to the broad study topic; however, had no part in the design, analysis, reporting, nor interpretation of the research.

Institutional Review Board Statement: Survey data were collected under the Australian Census and Statistics Acts 1905; thus, ethics approval was not required.

Informed Consent Statement: The study used third party data. Data was anonymized before the authors accessed it.

Data Availability Statement: Access to the AUSNUT 2011-13 data file can be found at https:// www.foodstandards.gov.au/science/monitoringnutrients/ausnut/pages/default.aspx (accessed on 22 October 2020).

Acknowledgments: The authors would like to thank Emily Duve, Cynthia Wibisono, Hania RahimiArdabili, and Elif Inan-Eroglu for their contribution to the cost data collection.

Conflicts of Interest: The authors declare no conflict of interest.

\section{References}

1. Australian Institute of Health and Welfare. Nutrition Across the Life Stages. Cat. No. PHE 227; Australian Institute of Health and Welfare: Canberra, Australia, 2018.

2. Australian Institute of Health and Welfare, Australian Government. Poor Diet; Australian Institute of Health and Welfare, Australian Government: Canberra, Australia, 2019.

3. Australian Health Survey: Usual Nutrient Intakes. Available online: https://www.abs.gov.au/statistics/health/healthconditions-and-risks/australian-health-survey-usual-nutrient-intakes/2011-12 (accessed on 22 October 2020).

4. Machado, P.P.; Steele, E.M.; Levy, R.B.; Sui, Z.; Rangan, A.; Woods, J.; Gill, T.; Scrinis, G.; Monteiro, C.A. Ultra-processed foods and recommended intake levels of nutrients linked to non-communicable diseases in Australia: Evidence from a nationally representative cross-sectional study. BMJ Open 2019, 9, e029544. [CrossRef] 
5. Zahedi, H.; Kelishadi, R.; Heshmat, R.; Motlagh, M.E.; Ranjbar, S.H.; Ardalan, G.; Payab, M.; Chinian, M.; Asayesh, H.; Larijani, B.; et al. Association between junk food consumption and mental health in a national sample of Iranian children and adolescents: The CASPIAN-IV study. Nutrition 2014, 30, 1391-1397. [CrossRef] [PubMed]

6. Rauber, F.; da Costa Louzada, M.L.; Steele, E.M.; Millett, C.; Monteiro, C.A.; Levy, R.B. Ultra-Processed Food Consumption and Chronic Non-Communicable Diseases-Related Dietary Nutrient Profile in the UK (2008-2014). Nutrients 2018, 10, 587. [CrossRef] [PubMed]

7. Lee, A.J.; Kane, S.; Lewis, M.; Good, E.; Pollard, C.M.; Landrigan, T.J.; Dick, M. Healthy diets ASAP-Australian Standardised Affordability and Pricing methods protocol. Nutr. J. 2018, 17, 88. [CrossRef] [PubMed]

8. National Primary Healthcare Strategic Framework. Available online: https://www1.health.gov.au/internet/publications/ publishing.nsf/Content/NPHC-Strategic-Framework \{\}strategicoutcome3 (accessed on 22 October 2020).

9. Lewis, M.; Lee, A.J. Affording health during the COVID-19 pandemic and associated economic downturn. Aust. N. Z. J. Public Health 2020. [CrossRef] [PubMed]

10. Lee, A.; Mhurchu, C.N.; Sacks, G.; Swinburn, B.; Snowdon, W.; Vandevijvere, S.; Hawkes, C.; L'Abbé, M.; Rayner, M.; Sanders, D.; et al. Monitoring the price and affordability of foods and diets globally. Obes. Rev. 2013, 14, 82-95. [CrossRef]

11. Vandevijvere, S.; Mackay, S.; Waterlander, W. INFORMAS Protocol: Food Prices Module [Internet]. Available online: https: / / auckland.figshare.com/articles/journal_contribution/INFORMAS_Protocol_Food_Prices_Module/5627440/1 (accessed on 25 October 2020).

12. Lee, A.J.; Kane, S.; Ramsey, R.; Good, E.; Dick, M. Testing the price and affordability of healthy and current (unhealthy) diets and the potential impacts of policy change in Australia. BMC Public Health 2016, 16, 315. [CrossRef] [PubMed]

13. Mackay, S.; Buch, T.; Vandevijvere, S.; Goodwin, R.; Korohina, E.; Funaki-Tahifote, M.; Lee, A.; Swinburn, B. Cost and Affordability of Diets Modelled on Current Eating Patterns and on Dietary Guidelines, for New Zealand Total Population, Māori and Pacific Households. Int. J. Environ. Res. Public Health 2018, 15, 1255. [CrossRef]

14. Vandevijvere, S.; Young, N.; Mackay, S.; Swinburn, B.; Gahegan, M. Modelling the cost differential between healthy and current diets: The New Zealand case study. Int. J. Behav. Nutr. Phys. Act. 2018, 15, 16. [CrossRef] [PubMed]

15. Lewis, M.; McNaughton, S.A.; Rychetnik, L.; Lee, A.J. A systematic scoping review of the habitual dietary costs in low socioeconomic groups compared to high socioeconomic groups in Australia. Nutr. J. 2020, 19, 139. [CrossRef]

16. Drewnowski, A. The Nutrient Rich Foods Index helps to identify healthy, affordable foods. Am. J. Clin. Nutr. 2010, 91, 1095S-1101S. [CrossRef] [PubMed]

17. Wilson, N.; Nghiem, N.; Ni Mhurchu, C.; Eyles, H.; Baker, M.G.; Blakely, T. Foods and Dietary Patterns That Are Healthy, Low-Cost, and Environmentally Sustainable: A Case Study of Optimization Modeling for New Zealand. PLoS ONE 2013, 8 , e59648. [CrossRef]

18. Drewnowski, A.; Darmon, N. The economics of obesity: Dietary energy density and energy cost. Am. J. Clin. Nutr. 2005, 82, 265S-273S. [CrossRef] [PubMed]

19. Gupta, S.; Hawk, T.; Aggarwal, A.; Drewnowski, A. Characterizing Ultra-Processed Foods by Energy Density, Nutrient Density, and Cost. Front. Nutr. 2019, 6, 70. [CrossRef]

20. Drewnowski, A.; Gupta, S.; Darmon, N. An Overlap Between "Ultraprocessed" Foods and the Preexisting Nutrient Rich Foods Index? Nutr. Today 2020, 55, 75-81. [CrossRef]

21. Drewnowski, A.; Eichelsdoerfer, P. Can Low-Income Americans Afford a Healthy Diet? Nutr. Today 2010, 44, 246-249. [CrossRef] [PubMed]

22. Monteiro, C.A.; Levy, R.B.; Claro, R.M.; de Castro, I.R.R.; Cannon, G. A new classification of foods based on the extent and purpose of their processing. Cad. Saúde Pública 2010, 26, 2039-2049. [CrossRef]

23. Mackerras, D. Mis-match Between the Healthy Food and the Ultra-processed Food Classifications in Australia. Curr. Dev. Nutr. 2019, 3. [CrossRef]

24. Von Elm, E.; Altman, D.G.; Egger, M.; Pocock, S.J.; Gøtzsche, P.C.; Vandenbroucke, J.P. The Strengthening the Reporting of Observational Studies in Epidemiology (STROBE) statement: Guidelines for reporting observational studies. J. Clin. Epidemiol. 2008, 61, 344-349. [CrossRef] [PubMed]

25. Husereau, D.; Drummond, M.; Petrou, S.; Carswell, C.; Moher, D.; Greenberg, D.; Augustovski, F.; Briggs, A.H.; Mauskopf, J.; Loder, E. Consolidated Health Economic Evaluation Reporting Standards (CHEERS) statement. BMJ 2013, 346, f1049. [CrossRef]

26. AUSNUT 2011-2013 Food Nutrient Database. Available online: https://www.foodstandards.gov.au/science/monitoringnutrients/ ausnut/ausnutdatafiles/Pages/foodnutrient.aspx (accessed on 15 November 2020).

27. Fayet-Moore, F.; McConnell, A.; Kim, J.; Mathias, K.C. Identifying Eating Occasion-Based Opportunities to Improve the Overall Diets of Australian Adolescents. Nutrients 2017, 9, 608. [CrossRef]

28. Starck, C.; Blumfield, M.; Keighley, T.; Petocz, P.; Roesler, A.; Abbott, K.; Cassettari, T.; Marchall, S.; Fayet-Moore, F. NRAUS Australia New Zealand food category cost dataset. Dryad 2021. [CrossRef]

29. 2071.0-Census of Population and Housing: Reflecting Australia-Stories from the Census. 2016. Available online: https:/ / www.abs.gov.au/ausstats/abs@.nsf/Lookup/by\%20Subject/2071.0 \{\}2016 \{\}Main\%20Features \{\}Socio-Economic\% 20Advantage\%20and\%20Disadvantage \{\} 123 (accessed on 10 December 2020).

30. Drewnowski, A.; Maillot, M.; Darmon, N. Should nutrient profiles be based on $100 \mathrm{~g}, 100 \mathrm{kcal}$ or serving size? Eur. J. Clin. Nutr. 2009, 63, 898-904. [CrossRef] 
31. Australian Bureau of Statistics. 4364.0.55.001-Australian Health Survey: First Results, 2011-2012; Commonwealth of Australia: Canberra, Australia, 2014.

32. Australian Bureau of Statistics. 4363.0.55.001-Australian Health Survey: User's Guide, 2011-2013; Commonwealth of Australia: Canberra, Australia, 2013.

33. Monteiro, C.; Cannon, G.; Levy, R.; Moubarac, J.-C.; Jaime, P.; Martins, A.P.; Canella, D.; Louzada, M.; Parra, D. NOVA. The star shines bright. Position paper 2. World Nutr. 2016, 7, 28-38.

34. Monteiro, C.; Cannon, G.; Levy, R.; Moubarac, J.-C.; Louzada, M.; Rauber, F.; Khandpur, N.; Cediel, G.; Neri, D.; Martinez Steele, E.; et al. Ultra-processed foods: What they are and how to identify them. Public Health Nutr. 2019, 22, 936-941. [CrossRef]

35. 4363.0.55.001-Australian Health Survey: Users' Guide, 2011-2013. Discretionary Foods. Available online: https://www.abs.gov. au/ausstats/abs@.nsf/Lookup/4363.0.55.001Chapter65062011-13 (accessed on 10 December 2020).

36. Fulgoni, V.L., III; Keast, D.R.; Drewnowski, A. Development and Validation of the Nutrient-Rich Foods Index: A Tool to Measure Nutritional Quality of Foods. J. Nutr. 2009, 139, 1549-1554. [CrossRef] [PubMed]

37. Nutrient Reference Values for Australia and New Zealand. Available online: https://www.nrv.gov.au/ (accessed on 23 October 2020).

38. Household Income and Wealth, Australia: Key information from the Survey of Income and Housing 2017-18. Available online: https:/ / www.abs.gov.au/statistics/economy/finance/household-income-and-wealth-australia (accessed on 22 December 2020).

39. Department of Health and Ageing, National Health and Medical Research Council, Australian Government. Eat for Health Educator's Guide; Department of Health and Ageing, National Health and Medical Research Council, Australian Government: Canberra, Australia, 2013.

40. Roy, R.; Hebden, L.; Rangan, A.; Allman-Farinelli, M. The development, application, and validation of a Healthy eating index for Australian Adults (HEIFA-2013). Nutrition 2016, 32, 432-440. [CrossRef] [PubMed]

41. Dalwood, P.; Marshall, S.; Burrows, T.L.; McIntosh, A.; Collins, C.E. Diet quality indices and their associations with health-related outcomes in children and adolescents: An updated systematic review. Nutr. J. 2020, 19, 118. [CrossRef]

42. Golley, R.; Hendrie, G.; McNaughton, S. The Dietary Guidelines Index for Children and Adolescents (DGI-CA); CSIRO: Canberra, Australia, 2011.

43. Golley, R.K.; Hendrie, G.A.; McNaughton, S.A. Scores on the dietary guideline index for children and adolescents are associated with nutrient intake and socio-economic position but not adiposity. J. Nutr. 2011, 141, 1340-1347. [CrossRef]

44. R: A Language and Environment for Statistical Computing. Available online: https://www.R-project.org/ (accessed on 15 December 2020).

45. Wickham, H.; Averick, M.; Bryan, J.; Chang, W.; D’Agostino McGowan, L.; Francois, R.; Grolemund, G.; Hayes, A.; Henry, L.; Hester, J.; et al. Welcome to the tidyverse. J. Open Source Softw. 2019, 4, 1686. [CrossRef]

46. Rico-Campà, A.; Martínez-González, M.A.; Alvarez-Alvarez, I.; Mendonça, R.d.D.; de la Fuente-Arrillaga, C.; Gómez-Donoso, C.; Bes-Rastrollo, M. Association between consumption of ultra-processed foods and all cause mortality: SUN prospective cohort study. BMJ 2019, 365, 11949. [CrossRef]

47. Elizabeth, L.; Machado, P.; Zinöcker, M.; Baker, P.; Lawrence, M. Ultra-Processed Foods and Health Outcomes: A Narrative Review. Nutrients 2020, 12, 1955. [CrossRef] [PubMed]

48. Lane, M.M.; Davis, J.A.; Beattie, S.; Gómez-Donoso, C.; Loughman, A.; O’Neil, A.; Jacka, F.; Berk, M.; Page, R.; Marx, W.; et al. Ultraprocessed food and chronic noncommunicable diseases: A systematic review and meta-analysis of 43 observational studies. Obes. Rev. 2021, 22, e13146. [CrossRef]

49. Pagliai, G.; Dinu, M.; Madarena, M.P.; Bonaccio, M.; Iacoviello, L.; Sofi, F. Consumption of ultra-processed foods and health status: A systematic review and meta-analysis. Br. J. Nutr. 2021, 125, 308-318. [CrossRef]

50. Poti, J.M.; Braga, B.; Qin, B. Ultra-processed Food Intake and Obesity: What Really Matters for Health-Processing or Nutrient Content? Curr. Obes. Rep. 2017, 6, 420-431. [CrossRef]

51. Fardet, A.; Rock, E. Ultra-processed foods: A new holistic paradigm? Trends Food Sci. Technol. 2019, 93, 174-184. [CrossRef]

52. Cole, M.B.; Augustin, M.A.; Robertson, M.J.; Manners, J.M. The science of food security. NPJ Sci. Food 2018, 2, 14. [CrossRef] [PubMed]

53. Grieger, J.A.; Johnson, B.J.; Wycherley, T.P.; Golley, R.K. Comparing the Nutritional Impact of Dietary Strategies to Reduce Discretionary Choice Intake in the Australian Adult Population: A Simulation Modelling Study. Nutrients 2017, 9, 442. [CrossRef] [PubMed] 